\title{
Tehdit Altında Bir Bitki Olan Tuzkırgını (Asparagus lycaonicus P.H. Davis) Türünün Koruma Biyolojisi Özellikleri Üzerine Güncel Bir Değerlendirme
}

\author{
Okan ÜRKER ${ }^{1 *}$, Tamer KEÇELİ ${ }^{2}$ \\ ${ }^{1 *}$ Çankırı Karatekin Üniversitesi, Eldivan Sağllk Hizmetleri MYO, Tıbbi Hizmetler ve Teknikler Bölümü, Çevre \\ Sağllğı Programı, Çankırı. \\ ${ }^{2}$ Çankırı Karatekin Üniversitesi, Fen Fakültesi, Biyoloji Bölümü, Botanik Ana Bilim Dall, Uluyazı Yerleşkesi, \\ 18200, Çankirı
}

(ORCID: 0000-0002-5103-7757) (ORCID: 000-0001-7958-072X)

\begin{abstract}
$\ddot{O} \mathbf{z}$
Bu çalışmada Türkiye ve İran'da yayılış gösteren bir İran-Turan Fitocoğrafik Bölgesi’ne özgü bir tür olan Tuzkırgını (Asparagus lycaonicus P.H. Davis) türünün koruma biyolojisi açısından güncel değerlendirmesi yapılmıştır. İç Anadolu'da 8 bölgedeki 54 farklı lokalitede nokta-çizgi transekt ve kareleme metotları uygulanarak, genel flora-vejetasyon gözlemleri ile birey sayımları gerçekleştirilmiştir. 2019 yılı Mayıs-Eylül ayları içerisinde yapılan arazi çalışmaları sonucunda tek bir bölgenin farklı lokalitelerinden farklı alt populasyonlara ait toplamda 858 bireyin sayıldığı ve bunların yaklaşı \%20'sinin (182 birey) meyve formunda olduğu tespit edilmiştir. Bilinen mevcut lokasyonların haricinde türün yaşama ve/veya yayılım potansiyeli bulunan diğer 7 bölgedeki alternatif lokalitelerde kaydedilmemiştir. Dolayısıyla Türkiye populasyonları özelinde türün ilk kaydedildiği andan bugüne geçmişte olduğu gibi günümüzde de Bolluk Gölü (Konya İli, Cihanbeyli İlçesi) kıyılarının türün ana yaşam alanları olduğu gözlenmiştir. Aş̧ıı tuzlu ve sodalı toprakları habitat olarak tercih eden Tuzkırgını, CITES Sözleşmesi Ek listelerinde yer almamasına rağmen, Bern Sözleşmesi Ek-1 listesinde yer almaktadır. Türün İran'daki populasyonuna yönelik bilgi boşluğu doldurulana kadar IUCN tehlike kategorisinin EN B1-a, C2-a(i) statüsünde değerlendirilmesi önerilmiştir. Otlatma, anız yakma, tarım arazisi işgalleri gibi türün yaşam alanının yakınlarında devam eden çevresel baskılar söz konusu olmakla beraber, türe yönelik en kritik tehdidin; habitatını doğrudan bozma ve yayılış alanını geri dönüşümsüz biçimde yok etme riskinden dolayı ALKİM Fabrikası'na bağlı kullanımlar olduğu anlaşılmıştır. Öte yandan, bu tesisin uzun yıllardır bölgede Tuzkırgını'nın arazi işgalleri, anız, otlatma gibi faaliyetlerden dolayı yok olmasının önüne geçilmesinde büyük bir sorumluluk yüklenmiş olması türün geleceği açısından firsat yaratmaktadır. Bu nedenle gerçekleştirilecek uzun vadeli koruma planlarında bu tesisle işbirliği önem taşımaktadır.
\end{abstract}

Anahtar kelimeler: Tuzkırgını, Asparagus lycaonicus, Asparagaceae, Flora, Koruma Biyolojisi, Halofit, Tehlike Altında.

\section{A Current Evaluation on Conservation Biology Properties of Tuzkırgını (Asparagus lycaonicus P.H. Davis) that is an Endangered Plant Species}

\begin{abstract}
It was aimed that in this study, a current evaluation on conservation biology properties of Tuzkırgını ((Asparagus lycaonicus P.H. Davis) where distributes on Turkey and Iran which is Irano-Turan Element. Point intercept and quadrats have been selected as research methods in 54 different locations from 8 different regions in Central Anatolia, in between May and September 2019. As a result, 858 individuals were counted where just from one region's different locations and approximately 20\% (182 individuals) of them were determined to be in fruit form. So, only the coasts of Lake Bolluk (Konya Province, Cihanbeyli District-Turkey) are detected as the main habitat of this local species. While Tuzkırgını prefers the highly soils as habitat, is not listed in the annexes of CITES, it is listed in Annex-I of the Bern Convention. On the other hand, until the knowledge gap of Iran population is completed, it has been proposed to evaluate the IUCN red list category in EN B1-a, C2-a(i) status. Grazing, stubble burning and farmland occupations are secondary threats to the species. The most critical threat may be pointed out as ALKIM Co.'s potential land uses on the main habitat of the species. The fact that this facility has been
\end{abstract}

*Sorumlu yazar: okanurker@karatekin.edu.tr

Geliş Tarihi:25.04.2020, Kabul Tarihi: 08.07.2020 
undertaken a great responsibility in preventing the extinction of Tuzkırgını due to land occupations, stubble and grazing in the region for many years creates an opportunity for the future of the species. Therefore, cooperation with this facility is of great importance in the long-term protection plans to be realized.

Keywords: Tuzkırgını, Asparagus lycaonicus, Asparagaceae, Flora, Conservation Biology, Halophytic, Endangered.

\section{Giriş}

Bünyesinde ekolojik açıdan pek çok sıcak nokta barındıran, farklı doğal ekosistemlere ve konumu itibariyle hem Karadeniz hem de Akdeniz iklimlerinin özelliklerine sahip olan ülkemiz, zengin bir biyolojik çeşitliliğe sahiptir [1]. Anadolu'nun, Avrupa kıtasının bütünü kadar bitki türüne sahip olduğu bilinmektedir. Bu nedenle Anadolu, Dünya'nın en büyük ve en zengin tür çeşitliliğine sahip doğal botanik bahçelerinden biri olarak değerlendirilebilir [2]. Küresel iklim değişikliği ve atmosferde sera etkisi gösteren gazların artması, arazi kullanımı sonrası ekosistemlerin geri döndürülemez bir şekilde zarar görmesi, ormansızlaştırma, sucul ekosistemlerin kirletilmesi ve aşırı otlatma gibi etkenler, Anadolu'nun bu özelliğini tehdit etmektedir. Bütün bu olumsuz gelişmeler endemizm oranı yüksek olan Anadolu' daki biyolojik çeşitliliğin azalmasına ve türlerin yok olmasına neden olmaktadır [3].

Gün geçtikçe artan kentleşme, sanayileşme gibi nedenlerin ekosistemler üzerindeki olumsuz etkileri nedeniyle, ülkemizin biyolojik çeşitliliğini korumak maksadıyla korumada öncelik arz eden türlerin tespitinin yapılarak, koruma biyolojisi ilkelerinin göz önünde tutulduğu bir eylem planı kapsamında türlerin korunması ve izlenmesi önem arz etmektedir [4]. Bu çalışma kapsamında da tehdit altında lokal bir bitki türü olan Tuzkırgını (Asparagus lycaonicus)'nın uzun vadeli ve sürdürülebilir biçimde yaşamını devam ettirebilmesi amacıyla güncel koruma biyolojisi özellikleri araştırılarak, alınması gerekli tedbirler bir eylem planı şeklinde özetlenmiştir. İki aşamada yürütülen bu çalışmanın ilk bölümünde, öncelikle arazi çalışmaları ile türün yayılışı, popülasyon durumu ile mevcut ve öngörülebilen tehditleri tespit edilmiştir. Tespitler yalnızca arazi çalışmaları ile sınırlı kalmamış yöre halkı, kamu kurum ve kuruluşlarıyla da görüşmeler yapılarak, türe yönelik bilgi düzeyleri hakkında görüşleri alınmıştır. İkinci aşamada ise arazi ve literatür kayıtları ile desteklenen tehditlere yönelik faaliyetler ve önlemler tespit edilmiştir.

\subsection{Tür Hakkında Temel Bilgiler}

\subsubsection{Literatür Özeti}

4 Ağustos 1960 tarihinde P.H. Davis tarafindan Bolluk Gölü kıyılarından toplanarak 1980'li y1lların başında yine aynı bilim insanı tarafından endemik tür olarak teşhisi yapılan Asparagus lycaonicus taksonu 1983 yılında Türkiye Florası'na eklenmiş [5] ve Flora of Turkey'in 1984 yılında yayınlanan 8. cildinde yer almışırı [6] (Şekil 1-A).

Davis [5] tarafından Türkiye Florası'na eklenen Asparagus lycaonicus taksonu İranlı Botanik Uzmanı Hossein Akhani tarafindan yayınlanan bir makale sonucunda İran Florası'na da eklenmiștir [7]. Bahsi geçen bu makale çerçevesinde atıfta bulunulan türe ait örnekler, esasen 1986 y1lında İran'da Ostan-e Markazi (Arak), Kavir-e Meyghan'ın güneydoğusunda yer alan Arak Tuz Gölü'nün yüksek derecede tuzluluk arz eden kıyı bölümlerinden toplanılmıştır. Ancak toplanıldığ 1 dönem itibariyle teşhisleri tam olarak bitirilmediği için İran Florası [8]'na kaydı yapılmamıştır. Akhani, 1997 yılının Nisan ve Mayıs aylarında Kew Botanik Bahçesi (Edinburgh)'ne yaptığ bir ziyaret sırasında burada türün Türkiye Florası [6]'na ait Kew Koleksiyonu'ndaki materyallerini İran koleksiyonu olan kendi örnekleri ile karşılaştırmış ve İran ile Türkiye örneklerinin aynı türe ait olduğunu ilgili makalede açıklayarak A. lycaonicus tiplerini karşılaştırmalı biçimde doğrulamıştır (Şekil 1-B,C,D). 

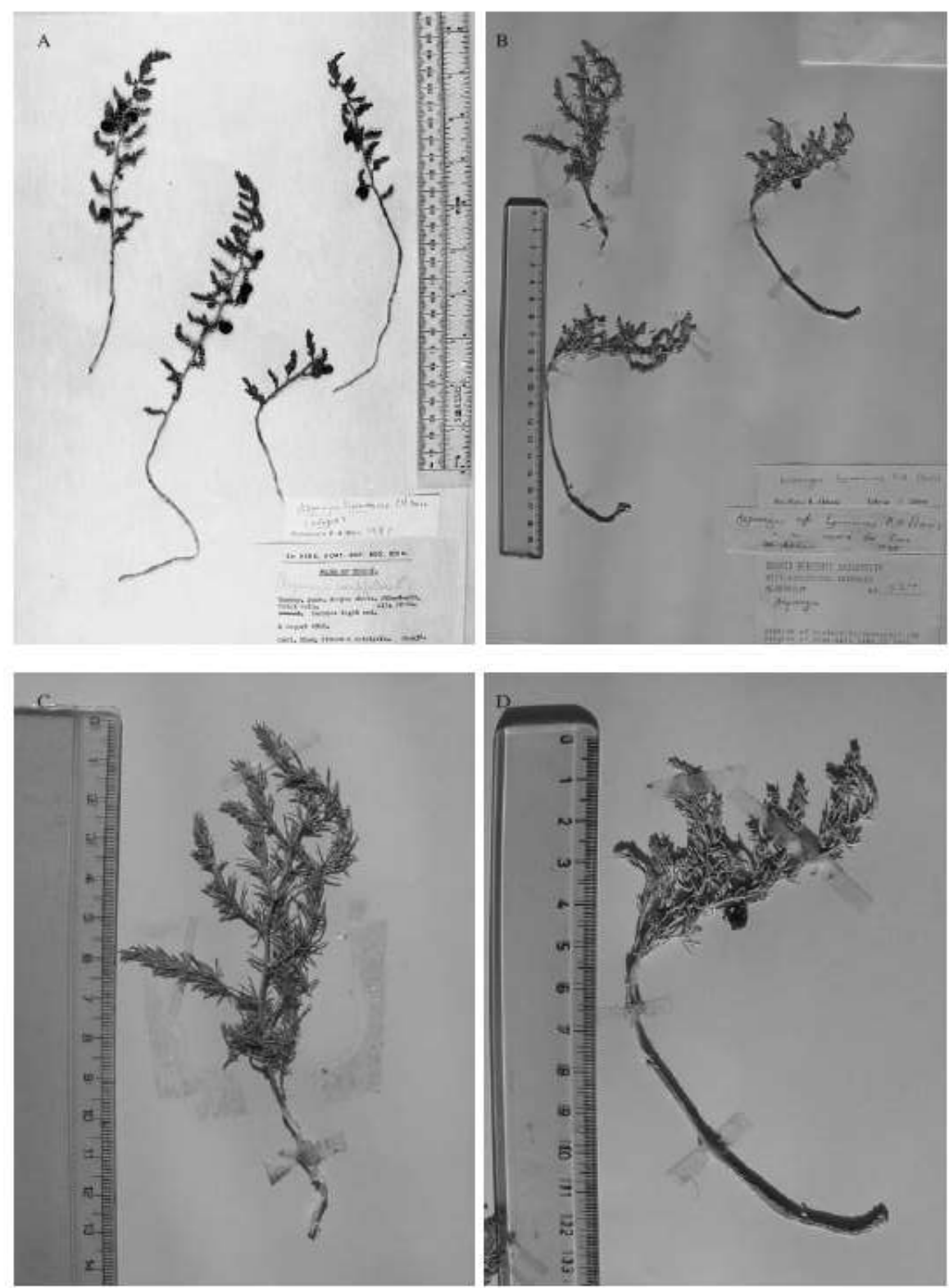

Şekil 1. A, Kuşkonmaz - A.lycaonicus, izotip (Kew Botanic Garden); B - D, İran koleksiyonu (H. Akhani 1124): B, sayfanın tamamı; C, büyütülmüş çiçekli bitki; D, büyütülmüş meyveli bitki

Tuna Ekim ve arkadaşları [9] tarafindan yayınlanan 'Türkiye Bitkileri Kırmızı Kitabı'na göre tehlike ve tehdit durumu ise EN (Endangered) / Tehlike Altında kategorisinde tanımlanmıştır. Türkiye Damarlı Bitkiler Listesi [10]'nde türe muhtemelen habitat özelliklerinden dolayı 'Tuzkırgını' adı verilmiştir. Dr. Akhani ile yapılan yazılı görüşmelerde Akhani tarafindan "İran bitkisi örneğinin Türkiye bitki örneğinin Edinburgh'daki numunesi karşılaştırılarak kontrol edildiği, İran populasyonuna benzeyen Türk popülasyonunun da doğal habitatında kendisi tarafindan ziyaret edildiği bildirilmiştir. İran bitki örneğinin kendisi tarafından yalnızca bir kez toplandığını ve bir daha bulamadığını belirten Akhani, hidrolojik sebepler veya habitat değişimi nedeniyle bu küçük populasyonun neslinin tükenmiş olabileceğini ifade etmiştir. Populasyonun yaşadığı lokalitelerde yeniden keşif çabalarının şu ana kadar başarısız olduğunu belirtmiştir (Ürker ve Keçeli, 2020; Kişisel yorum).

\subsubsection{Tür Üzerinde Yapılan Bilimsel Çalışmalar}

Literatürde doğrudan ve tek başına türü konu edinen herhangi bir bilimsel çalışmaya rastlanılmamakla beraber, tür ile ilgili yapılan en kapsamlı botanik araştırmaları Uzman Eczacı Ayşegül Güvenç tarafindan 1996 yılında tamamlanan "Türkiye'de yetişen Asparagus (Kuşkonmaz) türleri üzerinde 
farmasötik botanik yönünden araştırmalar" [11] isimli doktora tez çalışması kapsamında gerçekleştirilmiş ve türe ait oldukça önemli detay bulgular elde edilmiştir.

Özetle, bu çalışma kapsamında her ne kadar Türkiye'de yetişen Asparagus cinsine ait tüm taksonlar değerlendirilmekle birlikte A. lycaonicus'a yönelik spesifik ve detaylı botanik ve anatomik çalışmalar (gövde, kök vb.), kimyasal çalışmalar, mikrobiyolojik çalışmalar ve farmakolojik çalışmalar yürütülmüş olup, hali hazırda tür özelinde bugünkü güncel birçok bilgiye de bu çalışma sayesinde ulaşılabilinmektedir. Hülya Özler tarafindan yapılan "Asparagus L., Allium L., Muscari Mill. ve Fritillaria L. (Liliaceae) cinslerine ait bazı türlerin polenlerinin morfolojik yapılarının incelenmesi” [12] isimli bir başka doktora tez çalışması kapsamında ise A. lycaonicus'un da polen şekli, strüktürü, skülptürü incelenmiştir.

Nezahat Gökyiğit Botanik Bahçesindeki bölümlerden biri olan "Kurak ve Çorak Bahçe"de tuzkırgını da kültüre alınarak yetiştirilmiştir [13]. Atlas Dergisi yayını olan ve "Yok Olmadan Önce Görülmesi Gereken Son Cennetler Atlası" adını taşıyan kitapta Asparagus lycaonicus türünün Tersakan ve Bolluk gölleri civarlarında yayılış gösterdiğinden de bahsedilmektedir [14]. 11 Temmuz 1992'de M. Koyuncu, A. ve U. Güvenç ile birlikte Konya, Cihanbeyli, Bolluk Gölü, Alkim fabrikasının arkasındaki tuzlu ve sodalı alandan Asparagus lycaonicus türünü rapor etmişlerdir [11].

\subsubsection{Türün Taksonomik ve Morfolojik Özellikleri}

Tuzkırgını bitkisinin ait olduğu Asparagus cinsinin, APG IV sistemine göre güncel taksonomik durumu aşağıda özetlenmiştir [15]:

$\begin{array}{ll}\text { Üstalem (Superregnum) } & \text { : Eukaryota } \\ \text { Alem (Regnum) } & \text { : Plantae } \\ \text { Bölüm (Divisio) } & \text { : Magnoliophyta (Angiospermae) } \\ \text { Sinıf (Class) } & \text { : Liliopsida (Monocotyledoneae) } \\ \text { Ordo (Order) } & \text { : Asparagales } \\ \text { Aile (Family) } & \text { : Asparagaceae } \\ \text { Altaile (Subfamily) } & : \text { Asparagoideae } \\ \text { Oymak (Tribe) } & : \text { Asparageae } \\ \text { Altoymak (Subtribe) } & \text { : Asparaginae } \\ \text { Cins (Genus) } & : \text { Asparagus L. } \\ \text { Tür (Species) } & \text { : A. lycaonicus } \text { P.H. Davis }\end{array}$

Asparagus cinsi; Asparagaceae familyasının bir üyesi olup, eski dünyanın kurak ve yarı kurak bölgelerine dağılmış yaklaşık 300 tür içeren Asparagus, Protasparagus, Myrsiphyllum olmak üzere üç alt cinsten oluşmaktadır [16, 17]. Dünya'da 300 türü bulunan Asparagus L. (Asparagaceae) cinsinin bazı üyeleri gida (A. officinalis), süs bitkisi (A. asparagoides, A. medeloides, A. plumosus, A. sandens, A. setaceus, A. sprengeri) ve eczacılık açısından (A. acutifolius, A. setaceus, A. sprengeri) önemlidir [18].

Asparagus cinsinin anayurdu Akdeniz bölgesi olup, Güney Avrupa, Anadolu, Asya ve Afrika'da yayılış göstermektedir [19], [6], [20]. Ülkemizde Asparagus cinsinin 13 taksonu (10 tür, 3 alttür) bulunmaktadır, bunlardan 1'inin varlığı teyide muhtaç iken, 3 adedi endemiktir ve doğal olarak yetişmektedir [18]:

1. Asparagus acutifolius $\mathrm{L}$.

2. Asparagus aphyllus L. subsp. aphyllus

3. Asparagus aphyllus L. subsp. orientalis (Baker) P.H.Davis

4. Asparagus coodei P.H.Davis (Endemik)

5. Asparagus filifolius Bertol. (Türkiye'deki varlı̆̆ 1 teyide muhtaçtır)

6. Asparagus lycaonicus P.H.Davis (Endemik)

7. Asparagus lycius P.H.Davis (Endemik)

8. Asparagus officinalis L. subsp. officinalis

9. Asparagus palaestinus Baker

10. Asparagus persicus Baker

11. Asparagus tenuifolius Lam.

12. Asparagus trichophyllus Bunge

13. Asparagus verticillatus $\mathrm{L}$. 
Tuzkırgını türünün morfolojisi incelendiğinde; otsu $6-30 \mathrm{~cm}$ boyunda, genellikle toprak yüzeyine yatık gelişen, bazen yükselici dik bitki olduğu göze çarpmaktadır. Gövde oluklu köşelerde ince papilli, çıplak, sarımsı açık yeşil renkli ve pulsu yapraklar 0-1 $\mathrm{mm}$ boyunda dikensi olmayan mahmuz taşımaktadır. Esasen türün ayırt edici en baskın karakteri olarak kladotlar ön plana çıkmakta olup, bunlar her kümede 3-6 (-9) tane, 1- 10 (-25) mm boyunda 0,5 mm genişliğinde, oluklu, köşelerde papilli, etli, tepesi akut-mukronulat, dallara çok yatık, her kladot kümesinin tabanında zarımsı yapraklar yer almaktadır. Kladot kümeleri birbirine çok yakın ve sıktır [21]. Türün morfolojisine ait genel çizim Şekil 2 'de verilmiştir.

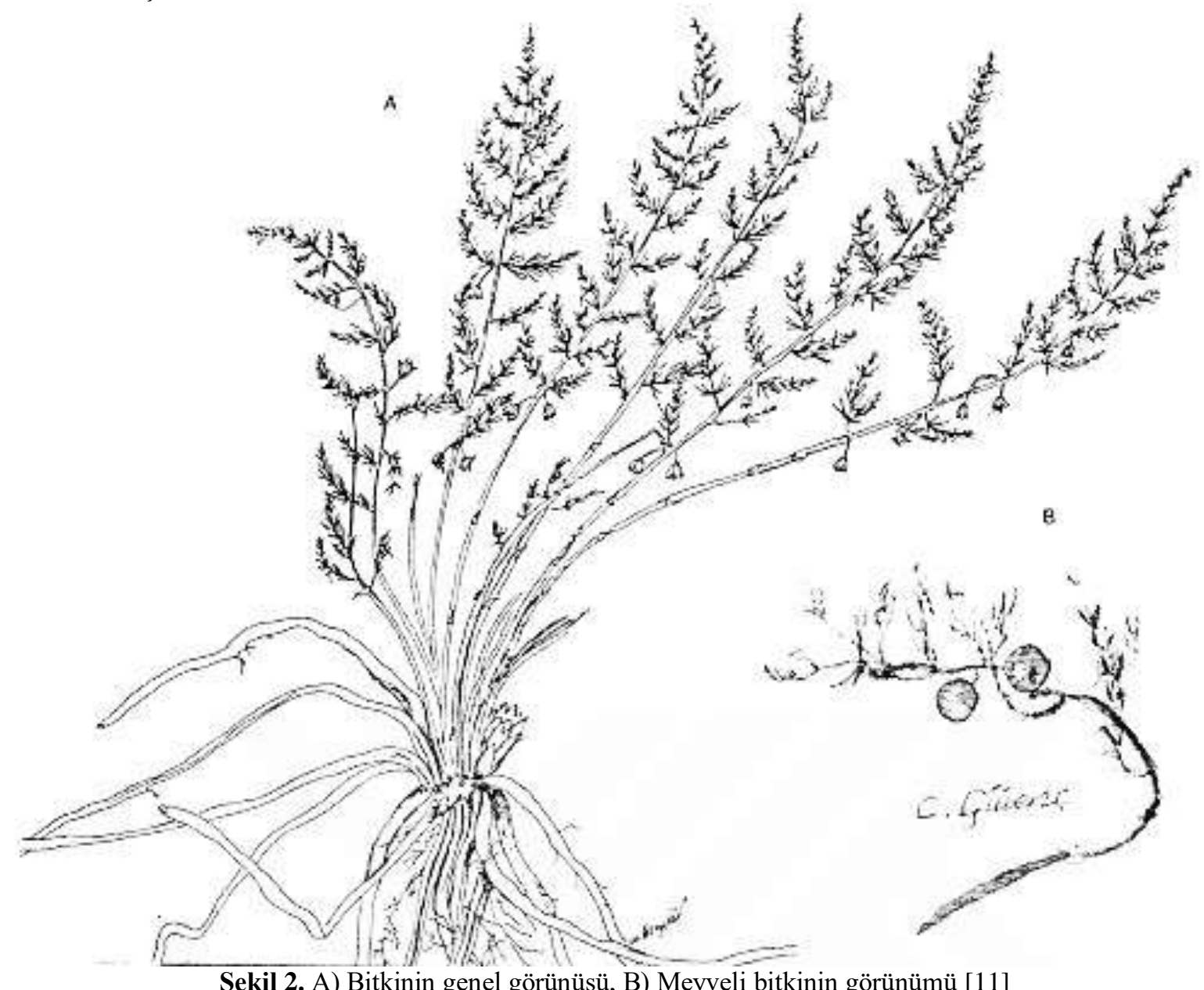

Çiçeklenmenin en iyi olduğu dönem 15 Mayıs-15 Haziran tarihleri arasında iken, bu durum yıllık iklimsel değişkenliklere göre birkaç hafta sarkmalar arz edebilmektedir. Çiçekler genellikle şeker pembemsi kırmızı veya turuncuya çalan kırmızımsı renkli olup, taze iken erkek çiçeklerden turuncu renkli anterler de rahatlıkla görülmektedir. Çiçekler genellikle 2 tane ve çoğunlukla ana gövde üzerinde yer almaktadır. Erkek çiçekler; 4-5 mm boyunda, kampanulat, dış tepaller iç tepallerden dar, iç tepallerin uçları yuvarlak, ginekeum gelişmemiş, stilus ve stigma taşımaz, stamenler gelişmiş ve 2 halka üzerinde dizilmiş olup, dış halkadaki stamenlerin filamentleri anterlerin biraz altından, iç halkadakiler ise daha aşağıdan tepallere bağlanmıştır $(3 \mathrm{~mm})$. Anterler $1 \mathrm{~mm}$ boyunda, $0,5 \mathrm{~mm}$ genişliğinde, küçük bir apendix taşırken, dişi çiçek 2.5-3 mm, ginekeumu gelişmiş, stigma üç parçalı, anter ve filamentler körelmiş olup, zarımsı yapıdadır. Pedisel eklemi ortada ve/veya bazen ortadan aşağıda (çiçeğe yakın), pediseller çiçeklerle aynı renkte, 4- $5 \mathrm{~mm}$ boyunda, çiçekle eklem arası pedisel boyu 1-2 mm, eklemden sonraki pedisel boyu 2-4 mm aralığındadır (Şekil 3). 850-1000 m'ler arasında yoğun tuzlu ve sodalı toprakların bulunduğu tuzcul bozkırlarda yetişen bu tür halofitik olarak da tanımlanabilir.

Meyve, koyu kırmızı renkli, tepaller kuruyunca meyve tabanında kalıcı bir iz bırakır, 5-7 mm çapında, 3 gözlü her gözde genellikle 2 tohum taşıyan bakka gözlenmekte, tohum sayısı genellikle 4-6 nadiren $1,2.5 \times 2-3 \times 2.55 \mathrm{~mm}$ boyutlarında ve siyah renklidir (Şekil 4). 

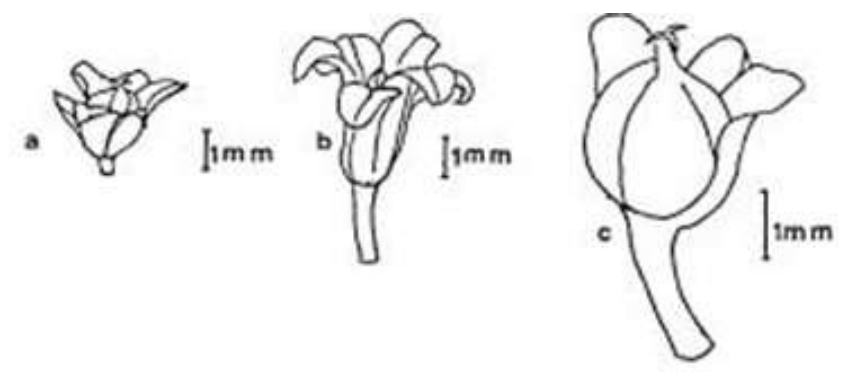

\section{A. lycaonicus : a ve c dişi çiçek, b ve d erkek çiçek}

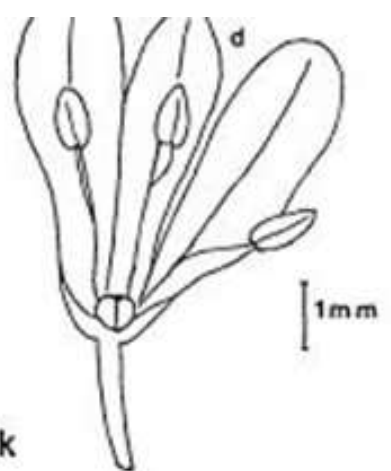

Şekil 3. Dişi çiçek ve erkek çiçeğe ait farklı çizimler [11]

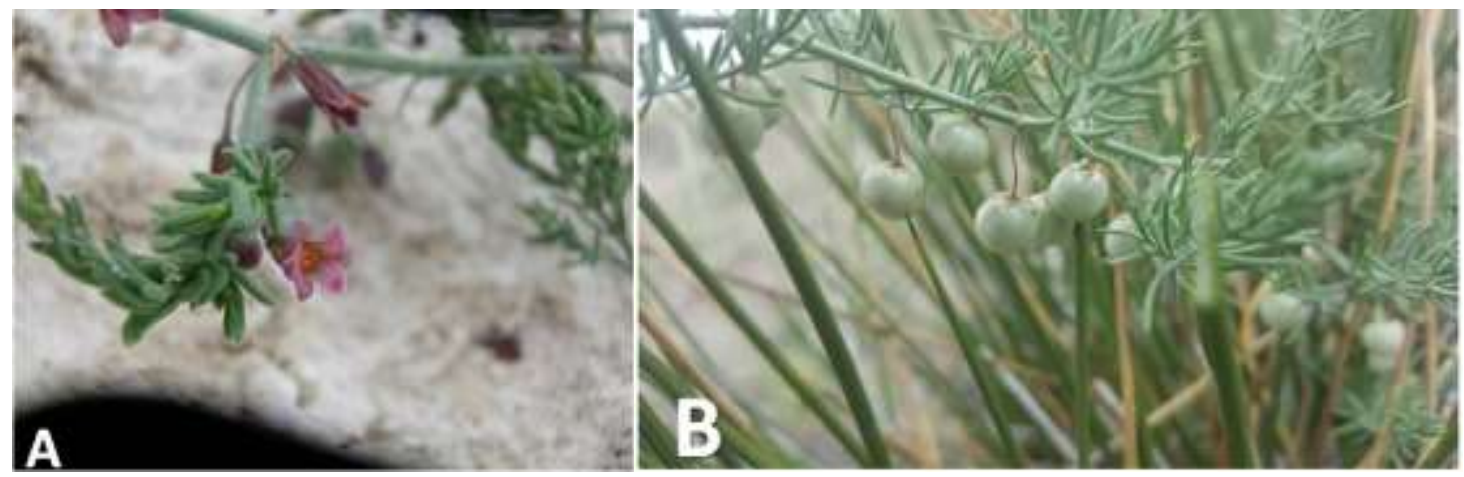

Şekil 4. A) Erkek bitki B) Dişi bitki (Fotoğraf: Mecit Vural)

Meyve, Temmuz-Ağustos döneminde görülmekle birlikte iklimsel değişimlere bağlı olarak Haziran ayında da gözlenebilmektedir. Tohumlar ise Ağustos-Ekim arasında olgunlaşmaktadır. Dişi bitkilerde meyve gelişimi sırasında çiçeklere ait çiçek yaprakları uzun süre kahverengimsi bir şekilde meyve üzerinde kalabilir. Bitkinin vejetatif bölümü yıl boyunca toprak üstünde görülmekle beraber Eylül ortasından itibaren sonbahar boyunca kuruyan bazı bitkiler sarımsı-kahverengimsi formlarda da gözlenebilir (Şekil 5).

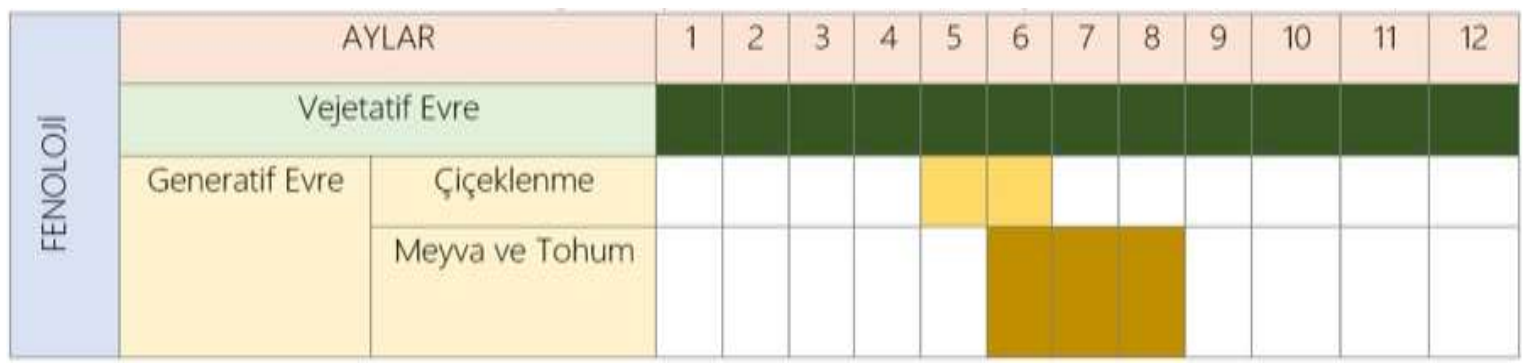

Şekil 5. Tuzkırgını (A. lycaonicus) bitkisinin fenolojisi

Bitkinin kök anatomisi özetlenecek olursa; epiderma, çoğunlukla parçalanmış olup, dış yüzeyde emici tüyler görülebilir. Hipoderma 4-5 sıralı, kahverengi çift çeperli, karakteristik şekilleri olmayan hücreler halinde de olabilir. Hipodermanın hemen altındaki birkaç sıra korteks parankiması ezilmiş hücrelerden; daha sonrakiler ise düzgün, yuvarlak, hücre arası boşlukları olan hücrelerden meydana gelmeltedir. Endoderma at nalı şeklinde kalınlaşma gösterir. Floem ve ksilem yan yana almaç dizilmiş ve 13-15 kolludur. Floem, ince çeperli değişik büyüklükte hücrelerden oluşmaktadır. Öz bölgesi genellikle selüloz çeperli yuvarlak hücre arası boşluklara sahiptir. Rafit demetleri ise gözlenmemektedir [22]. Bitkinin gövde anatomisi özetlenecek olursa; epiderma kalın çeperli uzun hücrelerden oluşmakta olup, korteks yuvarlak, 10-11 siralı ve rafit bulunmaz, sklerenkima 3-5 siral1, iletim demetleri 3-4 siralı iken, öz selülözitik ve rafit gözlenir. Kütikula ince, epiderma köşeli, palizat 3-(-4) sıralı ve rafit demeti taşır, sünger 2-3 sıralı ve rafit demeti taşır, iletim demetleri 2 büyük, 2-(3) küçük, öz; az bir (9-15) hücre odunlaşmış durumdadır. Bitkinin genel habitat özelliklerini ise tuzlu ve sodalı topraklar oluşturmakta olup, bitki bu habitat tercihinden dolayı halofitik olarak tanımlanabilir [22] (Şekil 6). 


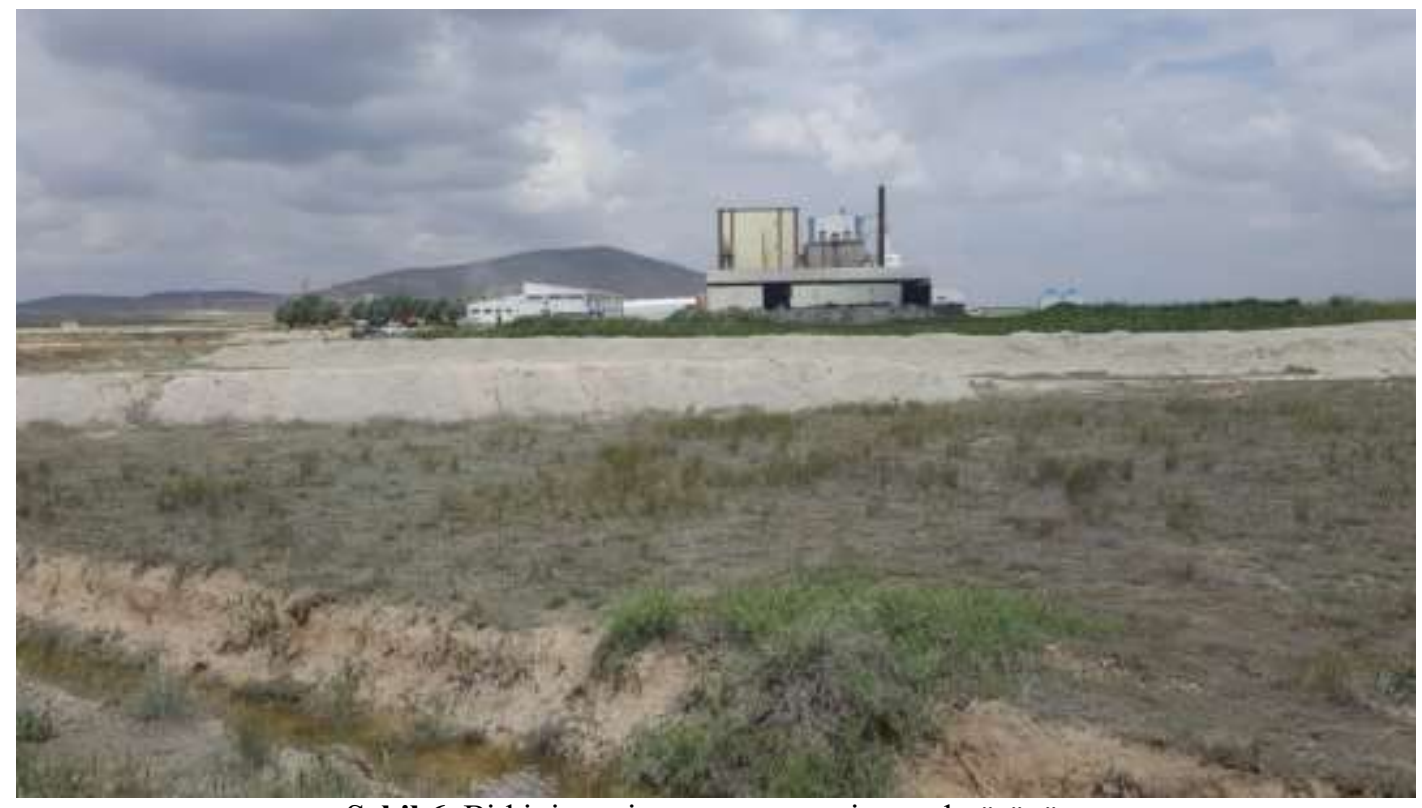

Şekil 6. Bitkinin yetişme ortamına ait genel görünüm

\section{Materyal ve Metot}

\section{1. Çalışma Alanı}

Tuzkırgını (Asparagus lycaonicus) türüne ait arazi çalışmaları, öncelikle Konya İli Cihanbeyli İlçesi sınırları dahilinde yer alan ve daha önceden farklı bilimsel çalışmalar kapsamında tespit edilen lokasyonlar (Bolluk Gölü kıyıları) başta olmak üzere türün yayılış gösterebileceği potansiyel alanlar da belirlenerek yürütülmüştür. Türün yayılış bilgileri incelendiğinde; Bolluk Gölü dışında habitat özellikleri nedeniyle türe ait populasyonların bulunma potansiyeli olabilecek farklı alanlar da (Konya İli Cihanbeyli İlçesi; Tersakan Gölü kıyıları, Tuz Gölü'nün batı ve güneybatı kıyıları, Konya İli Kulu İlçesi; Düden Gölü, Gök Gölü, Samsam Gölü kıyıları, Ankara İli Bala İlçesi; Çöl Gölü ve Uyuz Gölü kıyıları) dikkate alınarak arazi çalışmaları genişletilmiş, başlangıçta 1 lokasyon olarak planlanan arazi çalışmaları 8 lokasyonda, 54 noktada yapılmıştır. Arazi çalışması yapılan lokasyonlar aşağıdaki haritada gösterilmiştir (Şekil 7).

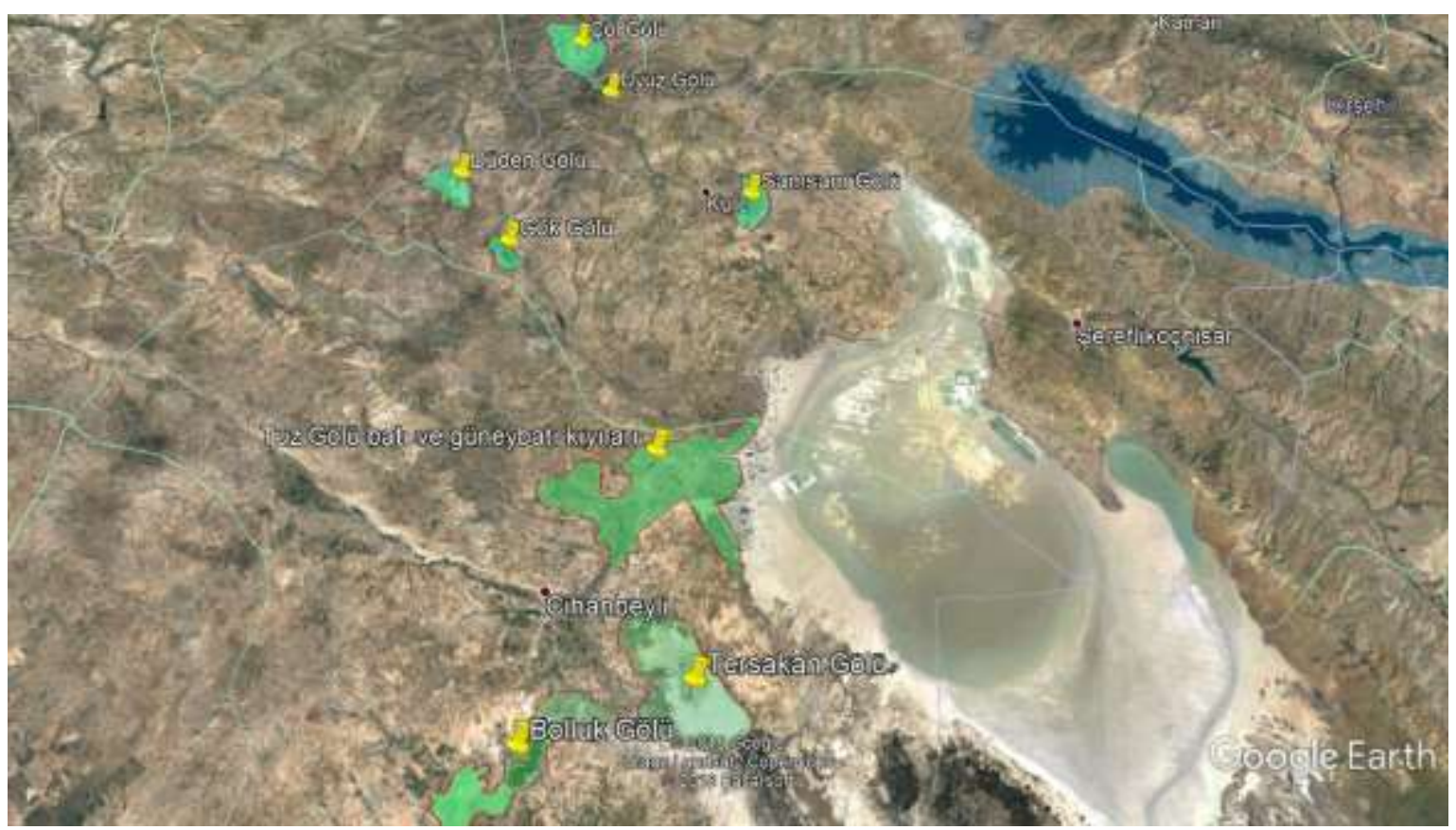

Şekil 7. Çalışma alanına ait yer bulduru haritası 


\subsection{Metot}

Saha çalışması yapılan lokaliteler ve bu noktalarda elde edilen gözlem bilgilerine ait detaylı veriler aşağıdaki tabloda özetlenmiştir (Tablo 1). Türün daha fazla tehdit altına girmesini engellemek amacıyla tabloda koordinat bilgilerine yer verilmemiştir. Her bir gözlem lokalitesinin özellikleri arazi defterlerine kaydedilmiş olup, bu veriler arasında alanın hâkim bitki örtüsü, arazinin konumu, eğimi, genel görünümü, GPS koordinatları (enlem-boylam), deniz seviyesinden yükseklik bilgisi gibi veriler rapor edilmiştir. Bu 54 farklı lokalitede line transekt metodu ve 100, 400, 1000 metrekarelik kareleme sistemleri uygulanarak, genel flora ve vejetasyon gözlemleri ile tür sayımı (vejetatif ve generatif formlar da kaydedilerek) gerçekleştirilmiştir. Türün yayılış gösterdiği habitatları tanıtıcı fotoğraflar da çekilmiştir.

Bitki örnekleme çalışmalarında bugüne kadar birçok metot geliştirilip kullanılmıştır. Bunlardan bazıları; Braun-Blanquet, nokta transekt, nokta-çizgi transekt, kare, dikdörtgen ve daire kuadrat teknikleri olarak özetlenebilir [23-29].

Kısa zamanda çabuk ve doğru sonuçlar verebilmesi, aynı anda aynı veriyi kullanarak vejetasyon yapısı ve bitki komünite parametreleri hakkında çeşitli yorumlara ulaşma imkânı sunmasından dolayı bu çalışmada tür araştırıldığı lokalitede tespit edilene kadar 'nokta-çizgi transekt metodu' (point intercept method) [24, 30] ile takip edilerek, gözlendiği noktadan itibaren ise birey sayımlarını gerçekleştirebilmek için kare kuadrat teknikleri tercih edilmiştir [23, 24].

Tablo 1. Arazi çalışmalarına ait lokalite detay bilgileri

\begin{tabular}{|c|c|c|c|c|}
\hline No & Tarih & Lokalite & Rakım (m) & Açıklama \\
\hline 1 & 21.6.2019 & $\begin{array}{l}\text { Bolluk Gölü, } \text { Alkim } \\
\text { Fabrikası civarı, drenaj } \\
\text { kanalı kenarı, yığma } \\
\text { toprak kuzey yamaçları }\end{array}$ & 951 & $\begin{array}{l}100 \mathrm{~m}^{2} \text { alanda } 42 \text { Asparagus lycaonicus } \\
\text { öbeği sayıld1, sayılan örneklerin toplam } \\
\% 30 \text { 'unda meyve görüldü. }\end{array}$ \\
\hline 2 & 21.6.2019 & $\begin{array}{l}\text { Bolluk Gölü, Alkim Fab. } \\
\text { civarı, drenaj }\end{array}$ & 950 & $\begin{array}{l}100 \mathrm{~m}^{2} \text { alanda } 48 \text { Asparagus lycaonicus } \\
\text { öbeği sayıld1, sayllan örneklerin toplam } \\
\% 15 \text { 'inde meyve görüldü. }\end{array}$ \\
\hline 3 & 21.6.2019 & $\begin{array}{l}\text { Bolluk Gölü, Alkim Fab. } \\
\text { civarı, drenaj } \\
\text { kenarı, kanalı } \\
\text { doğu yamaçları }\end{array}$ & 950 & $\begin{array}{l}100 \mathrm{~m}^{2} \text { alanda } 72 \text { Asparagus lycaonicus } \\
\text { öbeği sayıld1, sayilan örneklerin toplam } \\
\% 15 \text { 'inde meyve görüldü. }\end{array}$ \\
\hline 4 & 21.6.2019 & $\begin{array}{l}\text { Bolluk Gölü, Alkim Fab. } \\
\text { civarı, drenaj kanalı } \\
\text { kenarı, yığma toprak } \\
\text { kuzeydoğu yamaçları }\end{array}$ & 949 & $\begin{array}{l}100 \mathrm{~m}^{2} \text { alanda } 45 \text { Asparagus lycaonicus } \\
\text { öbeği sayıld1, sayilan örneklerin toplam } \\
\% 10 \text { 'unda meyve görüldü. }\end{array}$ \\
\hline 5 & 21.6.2019 & $\begin{array}{l}\text { Bolluk Gölü, Alkim Fab. } \\
\text { güneydoğusu, drenaj } \\
\text { kanalı kuzeyi }\end{array}$ & 948 & $\begin{array}{l}400 \mathrm{~m}^{2} \text { alanda } 90 \text { Asparagus lycaonicus } \\
\text { öbeği sayıldı, sayılan örneklerin toplam } \\
\% 30 \text { 'unda meyve görüldü. }\end{array}$ \\
\hline 6 & 21.6.2019 & $\begin{array}{l}\text { Bolluk Gölü, Alkim Fab. } \\
\text { güneydoğusu }\end{array}$ & 949 & $\begin{array}{lrlr}400 \mathrm{~m}^{2} & \text { alanda } & 105 \quad \text { Asparagus } \\
\text { lycaonicus } & \text { öbeği } & \text { sayıldı, } & \text { sayilan } \\
\text { örneklerin toplam } & \% 25 \text { 'inde } & \text { meyve } \\
\text { görüldü. } & & & \end{array}$ \\
\hline 7 & 21.6.2019 & $\begin{array}{l}\text { Bolluk Gölü, Alkim Fab. } \\
\text { doğusu }\end{array}$ & 951 & $\begin{array}{l}400 \mathrm{~m}^{2} \text { alanda } 5 \text { Asparagus lycaonicus } \\
\text { öbeği sayıld1, say1lan örneklerin toplam } \\
\% 20 \text { 'sinde meyve görüldü. }\end{array}$ \\
\hline 8 & 21.6.2019 & $\begin{array}{l}\text { Bolluk Gölü, Alkim Fab. } \\
\text { doğusu }\end{array}$ & 952 & $\begin{array}{l}400 \mathrm{~m}^{2} \text { alanda hiç Asparagus lycaonicus } \\
\text { örneği görülmedi. }\end{array}$ \\
\hline 9 & 22.6.2019 & $\begin{array}{l}\text { Bolluk Gölü, Alkim Fab. } \\
\text { civarı, drenaj } \\
\text { kenarı, kanalı } \\
\text { kuzey yamaçları }\end{array}$ & 965 & $\begin{array}{l}100 \mathrm{~m}^{2} \text { alanda } 2 \text { Asparagus lycaonicus } \\
\text { öbeği sayıldı, sayılan örneklerde meyve } \\
\text { görülmedi. }\end{array}$ \\
\hline 10 & 22.6.2019 & $\begin{array}{l}\text { Bolluk Gölü, Alkim Fab. } \\
\text { civarı, drenaj }\end{array}$ & 946 & $\begin{array}{lrlr}100 \mathrm{~m}^{2} & \text { alanda } & 152 & \text { Asparagus } \\
\text { lycaonicus } & \text { öbeği } & \text { sayıldı, } & \text { sayılan } \\
\text { örneklerin } & \text { toplam } & \% 25 \text { 'inde } & \text { meyve } \\
\text { görüldü. } & & & \end{array}$ \\
\hline
\end{tabular}




\begin{tabular}{|c|c|c|c|c|}
\hline 11 & 22.6 .2019 & \begin{tabular}{l}
\multicolumn{3}{l}{ Bolluk Gölü, Alkim Fab. } \\
civarı, drenaj
\end{tabular} & 922 & $\begin{array}{lrlr}100 \quad \mathrm{~m}^{2} & \text { alanda } & 180 & \text { Asparagus } \\
\text { lycaonicus } & \text { öbeği } & \text { sayıld1, } & \text { sayılan } \\
\text { örneklerin } & \text { toplam } & \% 15 \text { 'inde } & \text { meyve } \\
\text { görüldü. } & & & \end{array}$ \\
\hline 12 & 5.7.2019 & $\begin{array}{l}\text { Tersakan Gölü kuzeybatı } \\
\text { kıyıları }\end{array}$ & 921 & $\begin{array}{l}100 \mathrm{~m}^{2} \text { alanda hiç Asparagus lycaonicus } \\
\text { örneği görülmedi. }\end{array}$ \\
\hline 13 & 5.7.2019 & $\begin{array}{l}\text { Tersakan Gölü kuzeybatı } \\
\text { kıyıları }\end{array}$ & 923 & $\begin{array}{l}100 \mathrm{~m}^{2} \text { alanda hiç Asparagus lycaonicus } \\
\text { örneği görülmedi. } 60 \mathrm{~cm} \text { boyunda bir } \\
\text { Asparagus persicus öbeği görüldü. }\end{array}$ \\
\hline 14 & 5.7.2019 & $\begin{array}{l}\text { Tersakan Gölü kuzeybatı } \\
\text { kıyıları }\end{array}$ & 922 & $\begin{array}{l}100 \mathrm{~m}^{2} \text { alanda hiç Asparagus lycaonicus } \\
\text { örneği görülmedi. } 55 \mathrm{~cm} \text { boyunda bir } \\
\text { Asparagus persicus öbeği görüldü. }\end{array}$ \\
\hline 15 & 5.7.2019 & $\begin{array}{l}\text { Tersakan Gölü kuzeybatı } \\
\text { kıyıları }\end{array}$ & 922 & $\begin{array}{l}100 \mathrm{~m}^{2} \text { alanda hiç Asparagus lycaonicus } \\
\text { örneği görülmedi. } 35-50 \mathrm{~cm} \text { boylarında } \\
\text { dört Asparagus persicus öbeği görüldü. }\end{array}$ \\
\hline 16 & 5.7 .2019 & $\begin{array}{l}\text { Tersakan Gölü kuzeybatı } \\
\text { kıyıları }\end{array}$ & 923 & $\begin{array}{l}100 \mathrm{~m}^{2} \text { alanda hiç Asparagus lycaonicus } \\
\text { örneği görülmedi. } 25 \mathrm{~cm} \text { boyunda bir } \\
\text { Asparagus persicus öbeği görüldü. }\end{array}$ \\
\hline 17 & 5.7 .2019 & $\begin{array}{l}\text { Tersakan Gölü kuzeybatı } \\
\text { kıyıları }\end{array}$ & 923 & $\begin{array}{l}100 \mathrm{~m}^{2} \text { alanda hiç Asparagus lycaonicus } \\
\text { örneği görülmedi. } 40 \mathrm{~cm} \text { boyunda bir } \\
\text { Asparagus persicus öbeği görüldü. }\end{array}$ \\
\hline 18 & 5.7.2019 & $\begin{array}{l}\text { Tersakan Gölü kuzeybatı } \\
\text { kıyıları }\end{array}$ & 924 & $\begin{array}{l}100 \mathrm{~m}^{2} \text { alanda hiç Asparagus lycaonicus } \\
\text { örneği görülmedi. } 60-65 \mathrm{~cm} \text { boylarında } \\
\text { iki Asparagus persicus öbeği görüldü. }\end{array}$ \\
\hline 19 & 5.7 .2019 & $\begin{array}{l}\text { Bolluk Gölü, Alkim Fab. } \\
\text { kuzeydoğusu }\end{array}$ & 950 & $\begin{array}{l}400 \mathrm{~m}^{2} \text { alanda hiç Asparagus lycaonicus } \\
\text { örneği görülmedi. }\end{array}$ \\
\hline 20 & 5.7 .2019 & $\begin{array}{l}\text { Bolluk Gölü, Alkim Fab. } \\
\text { kuzeydoğusu }\end{array}$ & 950 & $\begin{array}{l}400 \mathrm{~m}^{2} \text { alanda hiç Asparagus lycaonicus } \\
\text { örneği görülmedi. }\end{array}$ \\
\hline 21 & 5.7.2019 & $\begin{array}{l}\text { Bolluk Gölü, Alkim Fab. } \\
\text { kuzeyi }\end{array}$ & 951 & $\begin{array}{l}400 \mathrm{~m}^{2} \text { alanda } 5 \text { Asparagus lycaonicus } \\
\text { öbeği sayıld1, sayılan örneklerin toplam } \\
\% 20 \text { 'sinde meyve görüldü. }\end{array}$ \\
\hline 22 & 5.7.2019 & $\begin{array}{l}\text { Bolluk Gölü, Alkim Fab. } \\
\text { kuzeyi }\end{array}$ & 953 & $\begin{array}{l}400 \mathrm{~m}^{2} \text { alanda hiç Asparagus lycaonicus } \\
\text { örneği görülmedi. }\end{array}$ \\
\hline 23 & 5.7.2019 & $\begin{array}{l}\text { Bolluk Gölü, Alkim Fab. } \\
\text { kuzeyi }\end{array}$ & 953 & $\begin{array}{l}400 \mathrm{~m}^{2} \text { alanda } 6 \text { Asparagus lycaonicus } \\
\text { öbeği sayıldı, sayılan örneklerde meyve } \\
\text { görülmedi. }\end{array}$ \\
\hline 24 & 5.7 .2019 & $\begin{array}{l}\text { Bolluk Gölü, Alkim Fab. } \\
\text { kuzeydoğusu }\end{array}$ & 957 & $\begin{array}{l}400 \mathrm{~m}^{2} \text { alanda } 1 \text { Asparagus lycaonicus } \\
\text { öbeği sayıldı, sayılan örnekte meyve } \\
\text { görülmedi. }\end{array}$ \\
\hline 25 & 5.7 .2019 & $\begin{array}{l}\text { Bolluk Gölü, Alkim Fab. } \\
\text { kuzeydoğusu }\end{array}$ & 962 & $\begin{array}{l}400 \mathrm{~m}^{2} \text { alanda hiç Asparagus lycaonicus } \\
\text { örneği görülmedi. }\end{array}$ \\
\hline 26 & 5.7 .2019 & $\begin{array}{l}\text { Bolluk Gölü, Alkim Fab. } \\
\text { doğusu }\end{array}$ & 960 & $\begin{array}{l}400 \mathrm{~m}^{2} \text { alanda } 1 \text { Asparagus lycaonicus } \\
\text { öbeği sayıld1, sayılan örnekte meyve } \\
\text { görülmedi. }\end{array}$ \\
\hline 27 & 5.7 .2019 & $\begin{array}{l}\text { Bolluk Gölü, Alkim Fab. } \\
\text { doğusu }\end{array}$ & 958 & $\begin{array}{l}400 \mathrm{~m}^{2} \text { alanda } 5 \text { Asparagus lycaonicus } \\
\text { öbeği sayıld1, sayılan örneklerin toplam } \\
\% 20 \text { 'sinde meyve görüldü. }\end{array}$ \\
\hline 28 & 6.7 .2019 & $\begin{array}{l}\text { Bolluk Gölü, Alkim Fab. } \\
\text { güneydoğusu }\end{array}$ & 948 & $\begin{array}{lccc}1000 \mathrm{~m}^{2} & \text { alanda } & 90 & \text { Asparagus } \\
\text { lycaonicus } & \text { öbeği } & \text { sayıldı, } & \text { sayılan } \\
\text { örneklerin toplam } \% 20 \text { 'sinde } & \text { meyve } \\
\text { görüldü. } & & & \end{array}$ \\
\hline 29 & 19.7.2019 & $\begin{array}{l}\text { Bolluk Gölü, Alkim Fab. } \\
\text { güneybatısı }\end{array}$ & 890 & $\begin{array}{l}1000 \mathrm{~m}^{2} \text { alanda hiç Asparagus } \\
\text { lycaonicus örneği görülmedi. }\end{array}$ \\
\hline 30 & 19.7.2019 & $\begin{array}{l}\text { Bolluk Gölü, Alkim Fab. } \\
\text { güneybatısı }\end{array}$ & 891 & $\begin{array}{l}1000 \mathrm{~m}^{2} \text { alanda hiç Asparagus } \\
\text { lycaonicus örneği görülmedi. }\end{array}$ \\
\hline 31 & 19.7.2019 & $\begin{array}{l}\text { Bolluk Gölü, Alkim Fab. } \\
\text { güneybatıs1, jipsli toprak }\end{array}$ & 893 & $\begin{array}{l}1000 \mathrm{~m}^{2} \text { alanda hiç Asparagus } \\
\text { lycaonicus örneği görülmedi. } 8-30 \mathrm{~cm} \\
\text { boylarında } 9 \text { Asparagus persicus öbeği } \\
\text { görüldü. }\end{array}$ \\
\hline
\end{tabular}




\begin{tabular}{|c|c|c|c|c|c|c|}
\hline 32 & 19.7.2019 & \multicolumn{3}{|c|}{$\begin{array}{l}\text { Bolluk Gölü, Alkim Fab. } \\
\text { güneybatısı, jipsli toprak }\end{array}$} & 893 & $\begin{array}{l}1000 \mathrm{~m}^{2} \text { alanda hiç Asparagus } \\
\text { lycaonicus örneği görülmedi. } 10-35 \mathrm{~cm} \\
\text { boylarında } 38 \text { Asparagus persicus öbeği } \\
\text { görüldü. }\end{array}$ \\
\hline 33 & 19.7.2019 & \multicolumn{3}{|c|}{$\begin{array}{l}\text { Bolluk Gölü, Alkim Fab. } \\
\text { güneybatısı, jipsli toprak }\end{array}$} & 893 & $\begin{array}{l}1000 \mathrm{~m}^{2} \text { alanda hiç Asparagus } \\
\text { lycaonicus örneği görülmedi. } 10-45 \mathrm{~cm} \\
\text { boylarında } 24 \text { Asparagus persicus öbeği } \\
\text { görüldü. }\end{array}$ \\
\hline 34 & 20.7.2019 & \multicolumn{3}{|c|}{$\begin{array}{l}\text { Bolluk Gölü, Alkim Fab. } \\
\text { batıs1 }\end{array}$} & 891 & $\begin{array}{l}1000 \mathrm{~m}^{2} \text { alanda hiç Asparagus } \\
\text { lycaonicus örneği görülmedi. } 20-30 \mathrm{~cm} \\
\text { boylarında } 2 \text { Asparagus persicus öbeği } \\
\text { görüldü. }\end{array}$ \\
\hline 35 & 20.7.2019 & \multicolumn{3}{|c|}{$\begin{array}{l}\text { Bolluk Gölü, Alkim Fab. } \\
\text { batısı }\end{array}$} & 894 & $\begin{array}{l}1000 \mathrm{~m}^{2} \text { alanda hiç Asparagus } \\
\text { lycaonicus örneği görülmedi. }\end{array}$ \\
\hline 36 & 20.7.2019 & \multicolumn{3}{|c|}{$\begin{array}{l}\text { Bolluk Gôlü, Alkım Fab. } \\
\text { batısı }\end{array}$} & 895 & $\begin{array}{l}1000 \mathrm{~m}^{2} \text { alanda } 10-25 \mathrm{~cm} \text { boylarında } 4 \\
\text { adet Asparagus lycaonicus öbeği } \\
\text { sayıldı. } 15-35 \quad \mathrm{~cm} \text { boylarında } 3 \\
\text { Asparagus persicus öbeği görüldü. }\end{array}$ \\
\hline 37 & 21.7.2019 & \multicolumn{3}{|c|}{$\begin{array}{l}\text { Bolluk Gölü, Alkim Fab. } \\
\text { Kuzeybatıs1, köprünün } \\
\text { kuzeybatısı mevkii }\end{array}$} & 896 & $\begin{array}{l}1000 \mathrm{~m}^{2} \text { alanda hiç Asparagus } \\
\text { lycaonicus örneği görülmedi. }\end{array}$ \\
\hline 38 & 21.7.2019 & \multicolumn{3}{|c|}{$\begin{array}{ll}\text { Bolluk Gölü, Alkim Fab. } & \text { Allörün } \\
\begin{array}{l}\text { kuzeyi, } \\
\text { güneydoğusu }\end{array} & \text { köprün }\end{array}$} & 900 & $\begin{array}{l}1000 \mathrm{~m}^{2} \text { alanda } 10-28 \mathrm{~cm} \text { boylarında } 5 \\
\text { adet Asparagus lycaonicus öbeği } \\
\text { sayıldı. } 65-70 \quad \mathrm{~cm} \text { boylarında } 1 \\
\text { Asparagus persicus öbeği görüldü. }\end{array}$ \\
\hline 39 & 7.7.2019 & \multirow{2}{*}{\multicolumn{3}{|c|}{$\begin{array}{l}\text { Tuz Gölü batı ve } \\
\text { güneybatı kıyıları } \\
\text { Tuz Gölü batı ve } \\
\text { güneybatı kıyıları }\end{array}$}} & 912 & $\begin{array}{l}1000 \mathrm{~m}^{2} \text { alanda hiç Asparagus } \\
\text { lycaonicus örneği görülmedi. }\end{array}$ \\
\hline 40 & 7.7.2019 & & & & 909 & $\begin{array}{l}1000 \mathrm{~m}^{2} \text { alanda hiç Asparagus } \\
\text { lycaonicus örneği görülmedi. }\end{array}$ \\
\hline 41 & 8.7.2019 & \multicolumn{3}{|c|}{ Samsam Gölü çevresi } & 970 & $\begin{array}{l}1000 \mathrm{~m}^{2} \text { alanda hiç Asparagus } \\
\text { lycaonicus örneği görülmedi. }\end{array}$ \\
\hline 42 & 8.7.2019 & \multicolumn{3}{|c|}{ Samsam Gölü çevresi } & 968 & $\begin{array}{l}1000 \mathrm{~m}^{2} \text { alanda hiç Asparagus } \\
\text { lycaonicus örneği görülmedi. }\end{array}$ \\
\hline 43 & 9.7 .2019 & \multicolumn{3}{|c|}{ Düden Gölü çevresi } & 1027 & $\begin{array}{l}1000 \mathrm{~m}^{2} \text { alanda hiç Asparagus } \\
\text { lycaonicus örneği görülmedi. }\end{array}$ \\
\hline 44 & 9.7 .2019 & \multicolumn{3}{|c|}{ Düden Gölü çevresi } & 1027 & $\begin{array}{l}1000 \mathrm{~m}^{2} \text { alanda hiç Asparagus } \\
\text { lycaonicus örneği görülmedi. }\end{array}$ \\
\hline 45 & 10.7.2019 & \multicolumn{3}{|c|}{ Gök Gölü çevresi } & 987 & $\begin{array}{l}1000 \mathrm{~m}^{2} \text { alanda hiç Asparagus } \\
\text { lycaonicus örneği görülmedi. }\end{array}$ \\
\hline 46 & 10.7.2019 & \multicolumn{3}{|c|}{ Gök Gölü çevresi } & 986 & $\begin{array}{l}1000 \mathrm{~m}^{2} \text { alanda hiç Asparagus } \\
\text { lycaonicus örneği görülmedi. }\end{array}$ \\
\hline 47 & 11.7.2019 & \multicolumn{3}{|c|}{ Çöl Gölü batı kıyıları } & 1056 & $\begin{array}{l}1000 \mathrm{~m}^{2} \text { alanda hiç Asparagus } \\
\text { lycaonicus örneği görülmedi. }\end{array}$ \\
\hline 48 & 11.7.2019 & \multicolumn{3}{|c|}{ Çöl Gölü doğu kıyıları } & 1057 & $\begin{array}{l}1000 \mathrm{~m}^{2} \text { alanda hiç Asparagus } \\
\text { lycaonicus örneği görülmedi. }\end{array}$ \\
\hline 49 & 11.7.2019 & \multicolumn{3}{|c|}{ Uyuz Gölü çevresi } & 1193 & $\begin{array}{l}1000 \mathrm{~m}^{2} \text { alanda hiç Asparagus } \\
\text { lycaonicus örneği görülmedi. }\end{array}$ \\
\hline 50 & 11.7.2019 & \multicolumn{3}{|c|}{ Uyuz Gölü çevresi } & 1193 & $\begin{array}{l}1000 \mathrm{~m}^{2} \text { alanda hiç Asparagus } \\
\text { lycaonicus örneği görülmedi. }\end{array}$ \\
\hline 51 & 2.8 .2019 & $\begin{array}{l}\text { Bolluk } \\
\text { kiyıları }\end{array}$ & & & 939 & $\begin{array}{l}1000 \mathrm{~m}^{2} \text { alanda hiç Asparagus } \\
\text { lycaonicus örneği görülmedi. }\end{array}$ \\
\hline 52 & 25.8.2019 & $\begin{array}{l}\text { Bolluk } \\
\text { kiyıları }\end{array}$ & & & 940 & $\begin{array}{l}1000 \mathrm{~m}^{2} \text { alanda hiç Asparagus } \\
\text { lycaonicus örneği görülmedi. }\end{array}$ \\
\hline 53 & 31.8 .2019 & $\begin{array}{l}\text { Bolluk } \\
\text { kiyıları }\end{array}$ & & kuzey & 942 & $\begin{array}{l}1000 \mathrm{~m}^{2} \text { alanda hiç Asparagus } \\
\text { lycaonicus örneği görülmedi. }\end{array}$ \\
\hline 54 & 1.9 .2019 & $\begin{array}{l}\text { Bolluk } \\
\text { kiyıları }\end{array}$ & Gölü & kuzey & 944 & $\begin{array}{l}1000 \mathrm{~m}^{2} \text { alanda hiç Asparagus } \\
\text { lycaonicus örneği görülmedi. }\end{array}$ \\
\hline
\end{tabular}




\section{Bulgular ve Tartışma}

\subsection{Floristik bulgular}

Yapılan arazi çalışmaları sonucunda eldeki veriler değerlendirildiğinde; tek bir lokalitenin farklı noktalarından farklı alt populasyonlara ait toplamda 858 bireyin sayıldığı, bunların 445 'inin erkek, 413'ünün dişi ve dişilerin de yaklaşık \%45'inin (182 birey) meyve formunda olduğu da anlaşılmaktadır. Tablo 1'de yer alan veriler değerlendirildiğinde; türe ait önceden bilinen mevcut lokasyonların haricinde türün yaşama ve/veya yayılış göstermea potansiyeli bulunan alternatif habitatlarda kaydedilmediği veya tespit edilemediği ifade edilmelidir. Dolayısıyla Türkiye populasyonları özelinde yorum yapılacaksa türün ilk kaydedildiği andan bugüne geçmişte olduğu gibi günümüzde de Bolluk Gölü kıyılarının türün ana yaşam alanları olduğu ifade edilmelidir.

Bolluk Gölü özelinde de ALKIMM Alkali Kimya A.Ş.'ne ait Cihanbeyli-Bolluk Tesisleri'nin hemen arkasında bulunan ve üç tarafı kanallar ile doğu bölümü de Bolluk Gölü kıyıları ile izole olmuş bir nevi adacık şeklindeki parsel türün ana sı̆̆ınma ve yaşam alanı olarak birinci derecede önem arz etmektedir. İlgili işletmenin giriş bölümünde ve işletme içerisindeki bağlantı yolları üzerinde de daha az yoğunlukta karşılaşılan populasyonlar ise koruma biyolojisi açısından nispeten ikincil önem arz etmektedir (Şekil 8). Bahsi geçen bu bölgenin mülkiyeti tamamen devlete ait olmakla birlikte yapılan protokoller kapsamında üst kullanım haklarının ALKIMM Alkali Kimya A.Ş.'ne devredildiği de bilinmektedir. Öte yandan, bu tesisin uzun yıllardır bölgede Tuzkırgını'nın arazi işgalleri, anız, otlatma gibi faaliyetlerden dolayı yok olmasının önüne geçilmesinde büyük bir sorumluluk yüklenmiş olması da türün geleceği açısından firsat yaratmaktadır. Bu nedenle gerçekleştirilecek uzun vadeli koruma planlarında bu tesisle işbirliği büyük önem taşımaktadır. Dolayısıyla türün yaşam alanı üzerindeki ana paydaş ALKİM Alkali Kimya A.Ş. olup, bu durum koruma biyolojisi açısından birçok avantaj sağlamakla beraber, ilgili işletmenin türün korunmasına yönelik personeline ve taşeronlarına sürdürülebilir bir eğitim ve izleme sunmadığı takdirde büyük bir risk de söz konusudur.

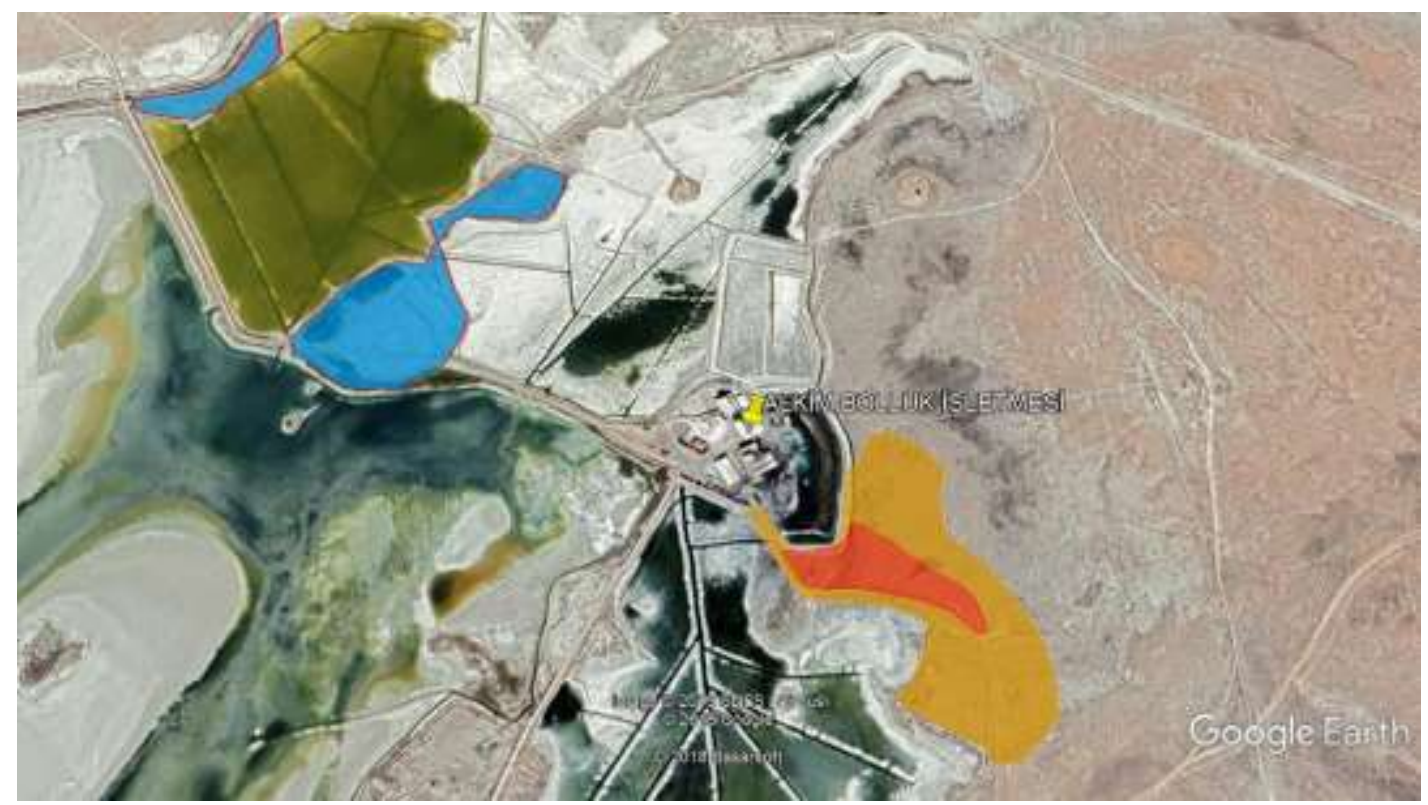

Şekil 8. Tuzkırgını'nın mevcut yayılış alanları

(Kırmızı renk: Mutlak Korunması Gereken Alan. Turuncu Renk: Kritik habitat. Mavi renk: Sekonder habitat)

Türe ait bireylerin tespit edildiği yoğun tuzcul ve sodalı bozkır habitatlarında; Noaea mucronata (Forssk.) Asch. \& Schweinf., Chenopodium glaucum L., Artemisia austriaca L., Jurinea pontica Hausskn. \& Freyn ex Hausskn., Cousinia halysensis Hub.-Mor., Centaurea carduiformis DC., Scorzonera cana (C.A.Mey.) Griseb., Nitraria schoberi L., Salicornia freitagii Yaprak \& Yurdak., Salsola kali L., Halocnemum strobilaceum (Pall.) M.Bieb., Juncus gerardi Loisel., Limonium iconicum (Boiss. \& Heldr.) Kuntze, Plantago maritima L., Salvia halophila Hedge ve Verbascum pyroliforme (Boiss. \& Heldr.) Kuntze gibi diğer tuzcul bozkır bitkileri ile birlikte yaşadığı gözlenmiştir. 
Türün yaşadığı bilinen ve tarafımızca da güncel durumu teyit edilen tek lokalite olan Bolluk Gölü kıyısı boyunca gözlenen halofit (tuzcul) bozkırlar ve bölgede yaygın dağılış arz eden esas bozkır tipi ise İran-Anadolu Bozkırlarıdır.

Bununla beraber her ne kadar bölge genellikle düz bir topoğrafya arz etse de zaman zaman gözlenen hafif yükselti çıkışlarının gözlendiği mıntıkalarda ilgili sahanın jeolojik formasyonlarına ve coğrafik oluşumlarına bağlı olarak ortaya çıkan kireçtaşı kayalıklı bozkır habitatları da bir başka habitat tipini teşkil etmektedir. Bahsi geçen bu habitat tipinin baskın bitki türleri olarak genellikle Thymus, Astragalus, Acanthalimon cinslerine ve Poaceae familyasına ait bazı taksonlar yaygındır. İç Anadolu bozkırlarını domine eden Festuca valesiaca Schleich. ex Gaudin, Acanthus hirsutus Boiss., Gundelia tournefortii L., var. tournefortii, Thymus sipyleus Boiss., Globularia trichosantha Fisch. \& C.A.Mey., Astragalus microcephalus Willd., Senecio vernalis Waldst. \& Kit., Xeranthemum annuum L., Echinophora tournefortii L., Carthamus lanatus L., Eryngium campestre L., Onosma briquetii Czeczott, Peganum harmala L., Achillea aleppica DC. subsp. zederbaueri (Hayek) Hub.-Mor., Achillea arabica Kotschy, Acantholimon acerosum L. subsp. acerosum var. acerosum ve Salvia absconditiflora (Montbret \& Aucher ex Benth.) Greuter \& Burdet taksonları türün yayılış gösterdiği habitatın yakın çevresindeki bozkır alanlarında da belirgin bir şekilde baskındır.

Bozkırlarda seyrek olarak Rosa canina L., Berberis crataegina DC. ve Juniperus oxycedrus L. subsp. oxycedrus gibi çalılara da rastlanılmaktadır. Öte yandan Tuzkırgını'nın gözlendiği lokalitenin yakın çevresinde yer alan kanallar boyunca da Bolluk Gölü ile etkileşim halinde olan çeşitli sürekli ve mevsimsel dereler ile kanal yapılarına bağlı olarak gelişen riparyan vejetasyon bünyesinde Tamarix smyrnensis Bunge, Elaeagnus angustifolia L., Lythrum salicaria L., Arundo donax L., Phragmites australis (Cav.) Trin. ex Steud., Ranunculus repens L. gibi su seven ağaç, çalı ve otsu türleri barındırmaktadır. Tuzkırgını türünün yayılış gösterdiği lokalitenin çevresinde gözlenen yol kenarlarında, tarla içlerinde ve tarla kenarlarında en çok rastlanan bitkiler ise Camelina laxa C.A.Mey., Capsella bursa-pastoris (L.) Medik., Brassica nigra (L.) W.D.J.Koch, Sisymbrium altissimum L., Reseda lutea L. var. lutea, Chenopodium botrys L., Centaurea solstitialis L. subsp. solstitialis, Cichorium intybus L., Anchusa azurea Mill. var. azurea, Anchusa leptophylla Roem. \& Schult. subsp. leptophylla, Heliotropium hirsutissimum Grauer, Convolvulus arvensis L., Echium italicum L., Fumaria asepala Boiss., Euphorbia rhabdotosperma Radcl.-Sm., Centaurea virgata Lam., Microthlaspi perfoliatum (L.) F.K.Mey., Vicia cracca Vel. subsp. stenophylla, Rumex crispus L., Alcea biennis Winterl ve Erodium cicutarium (L.) L Hér. subsp. cicutarium'dur.

\subsection{Türün Türkiye'deki ve dünyadaki durumu}

Tuzkırgını; Türkiye ve İran'da yayılış gösteren bir İran-Turan fitocoğrafik bölgesine özgü bir tür ve elementidir. İran'da Ostan-e Markazi (Arak), Kavir-e Meyghan'ın güneydoğusunda yer alan Arak Tuz Gölü'nün yüksek derecede tuzluluk arz eden kıyı bölümlerinden bilinmektedir. Türün İran populasyonuna ait güncel durum bilgisi bu bölgede türü toplayıp bilim dünyasına sunan Dr. Akhani tarafindan aktarılmış olup, ilk topladığı zaman diliminden bu yana geçen zaman diliminde bölgede türe ait bireylere rastlanılamadığı bilgisi verilmiştir. Ancak daha detaylı ve sistematik çalışmalar ışığında bu bölgedeki populasyon dinamiklerinin daha doğru biçimde ortaya çıkartılabileceği de ifade edilmiştir.

Türkiye'de tespit edildiği 1960'lı yıllardan Türkiye Florası'na kaydedildiği 1980'li yıllara, akabinde 1990'lı ve 2000'li yıllarda çeşitli botanik uzmanları ve farmakoloji uzmanlarının araştırmaları neticesinde de bilinen tek lokalitesi tarafımızca 2019 yılı Haziran-Eylül dönemi arasında gerç ekleştirilen arazi çalışmaları sonucunda da değişmemiş olup, dolayısıyla tür Türkiye'den halen tek bir lokaliteden (Konya İli Cihanbeyli İlçesi sınırlarında yer alan Bolluk Gölü'nün yoğun tuzlu ve sodalı kıyıları) bilinmektedir. Güncel arazi çalışmaları sonucunda tamamı ALKIMM Alkali Kimya A.Ş.’ne ait fabrika yapılarının etrafinda yaşayan yaklaşık 10 farklı populasyonun sayımı sonucunda 182'si meyve formunda olan 858 birey ile karşılaşılmaktadır. Hali hazırda türün Türkiye populasyonlarına ait güncel dağılım haritası Şekil 7'de sunulmuştur. Tuzkırgını'nın Türkiye ile İran Populasyonları arasındaki mesafe ise yaklaşık olarak $1500 \mathrm{~km}$ olup, Dünya ölçeğindeki dağılım haritası ise aşağıda sunulmuştur (Şekil 9). 


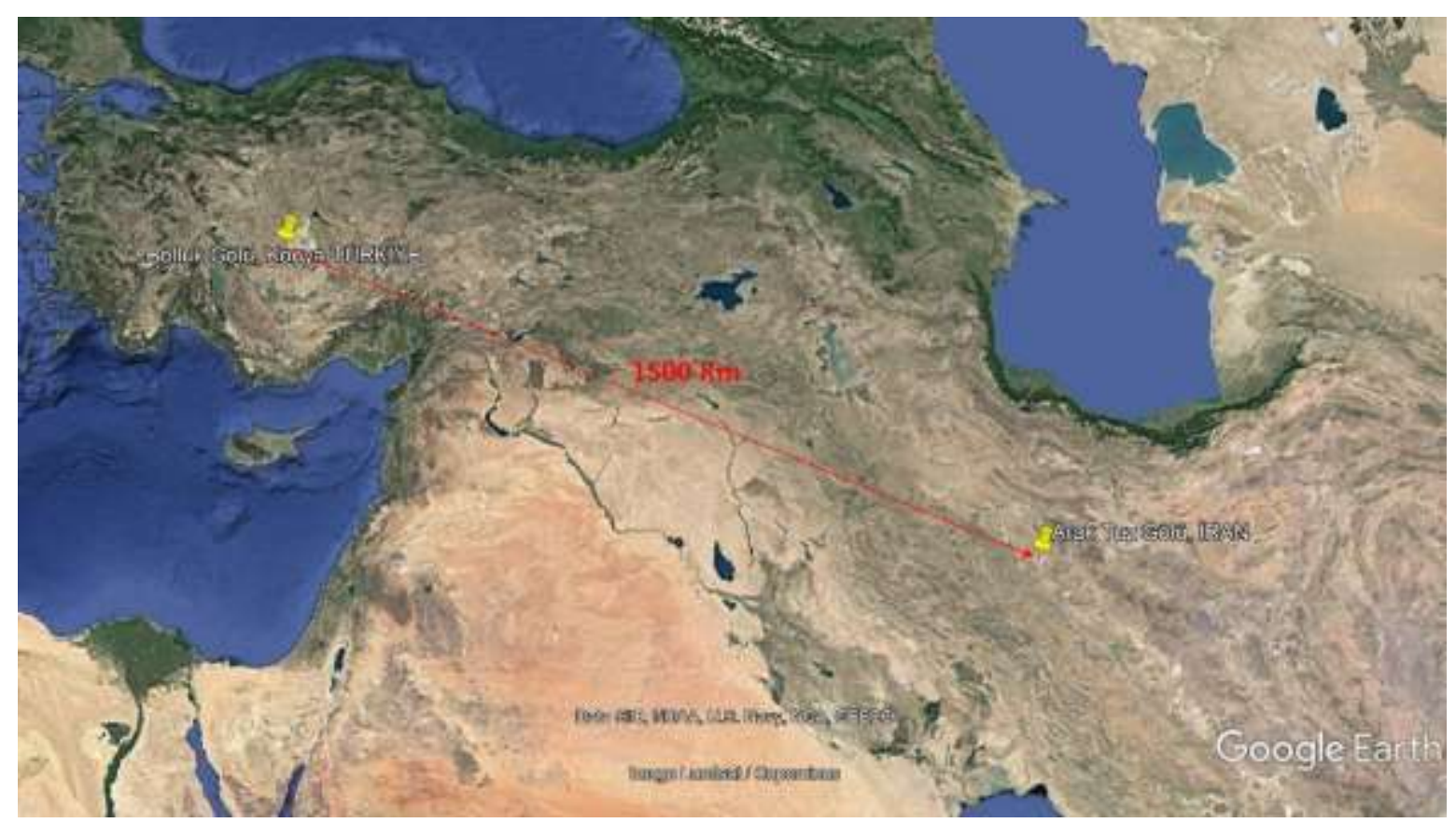

Şekil 9. Tuzkırgını’nın dünyadaki bilinen yayılış noktaları

\subsection{Türü tehdit eden ana faktörler}

Tuzkırgını bitkisini tehdit eden ve sınırlayıcı faktör olarak ele alınabilecek çeşitli problemler de bu çalışma kapsamında detaylı olarak ele alınmıştır. Tehdit unsurları aşağıdaki gibi 4 farklı öncelik düzeyinde ele alınmış olup, öncelik sırasının belirlenmesinde kullanılan ölçütler aşağıdaki gibidir [4];

- Kritik: Türün tamamen yok olmasina sebebiyet verebilecek sorunlar.

- Yüksek: 20 yıl veya daha az zamanda popülasyonunun \%20'sinden fazlasının yok olmasına sebebiyet verebilecek bir faktör.

- Orta: 20 yıl veya daha az zamanda popülasyonunun \%20'sinden azının yok olmasına sebebiyet verebilecek bir faktör.

- Düşük: Yerel popülasyon düşüşünün veya tüm ülke popülasyonunda küçük etki yapabilecek olan faktörler.

Literatür incelemesi ve arazi çalışmaları sırasında elde edilen bulguların değerlendirmesini takiben, türü tehdit eden altı ana problem tespit edilmiştir. Tehditler ve tehdit düzeyleri aşağıdaki tabloda gösterilmiş olup, tehditlerle ilgili ayrıntılı bilgiler aşağıda verilmiştir (Tablo 2).

Tablo 2. Tuzkırgını bitkisine yönelik tehditler ve tehdit düzeyleri

\begin{tabular}{|c|c|c|}
\hline $\begin{array}{l}\text { ALKİM Alkali Kimya A.Ş. } \\
\text { (Cihanbeyli-Bolluk Tesisleri)'ne } \\
\text { bağlı hafriyat, depolama, trafik ve } \\
\text { diğer arazi kullanımları }\end{array}$ & $\begin{array}{l}\text { Türün habitatını bozar, yayılış alanını } \\
\text { ortadan kaldırır, popülasyonun } \\
\text { genişlemesini engeller }\end{array}$ & Kritik \\
\hline $\begin{array}{l}\text { Yaşam alanlarının yakın çevresinin } \\
\text { tarım arazisine dönüştürülmesi }\end{array}$ & Popülasyonun genişlemesini engeller & Yüksek \\
\hline İklim değişimi & $\begin{array}{l}\text { Türün habitat özelliklerini değişime } \\
\text { uğratır }\end{array}$ & Yüksek \\
\hline Otlatma baskısı & Popülasyonun genişlemesini engeller & Orta \\
\hline Anız yakma & Popülasyonun genişlemesini engeller & Orta \\
\hline $\begin{array}{l}\text { Yöre halkı başta olmak üzere } \\
\text { paydaşların türün önemi hakkında } \\
\text { yeterince bilgi sahibi olmaması }\end{array}$ & $\begin{array}{l}\text { Koruma çalışmalarında paydaşların } \\
\text { katkısı olmayışı veya yetersizliği }\end{array}$ & Düşük \\
\hline
\end{tabular}




\subsection{Türün ulusal ve uluslararası koruma mevzuatı açısından güncel durumu}

Tuzkırgını'nın korunmasına yönelik ilgili ulusal mevzuat ve uluslararası sözleşmeler 1şığında değerlendirmesi yapıldığında; Bern Sözleşmesi çerçevesinde Tuzkırgını (Asparagus lycaonicus) "Ek Liste-I”de, yani “Avrupa Kıtası Ölçeğinde Kesin Olarak Koruma Altına Alınan Flora Türleri” listesinde yer almaktadır [31]. İş bu nedenden dolayı türe ilişkin gerçekleştirilecek eylem planı kapsamında düzenli olarak "Akit Taraflar” ile işbirliği yapılması ve Sözleşmeyi yürüten Sekreterya ile iletişim halinde bulunmak yararlı gözükmektedir. Öte yandan, uluslararası koruma statüsünde olan Tuzkırgını (Asparagus lycaonicus) bitkisinin CITES Sözleşmesi kapsamında "Liste dışı" olarak yer aldığı tespit edilmiştir [32]. Tuzkırgını (Asparagus lycaonicus) türü Dünya'da ve Türkiye'de 2 lokasyondan bilinmektedir. Türkiye Bitkileri Kırmızı Kitabı'nda ise ulusal Dünya Doğayı Koruma Birliği (IUCN) tehlike kategorisi Endangered (EN) - Tehlikede şeklinde belirlenmiştir [9]. Tuzkırgını'nın tehlike sınıfı mevcut IUCN kriterlerine göre değerlendirildiğinde şöyle belirlenebilir [33]:

Tehlike Altında (EN): Bir taksonun EN kategorisi içerisinde tanımlamasının yapılabilmesi ve doğada somut anlamda gerçekten ne ölçüde bir tehdit ile karşı karşıya kalındığının sınıflandırılmabilmesi için aşağıda A'dan E'ye sıralanmış listeler içerisindeki ilgili maddelerden ve kriterlerden bir veya birkaçının karşılanması gerekmektedir;

A. Aşağıdakilerden herhangi birine dayanarak Populasyon Büyüklüğ̈̈:

1. Son 10 yıl veya üç kuşak boyunca, hangisi daha uzun olursa olsun, azaltma nedenlerinin açıkça geri dönüşümlü olduğu gözlenen, tahmin edilen, çıkarılan veya şüphelenilen \% 70 'in üzerinde bir populasyon büyüklüğü azalması; aşağıdakilerden herhangi birine dayanarak (ve belirtilerek) anlaşıldı ise:

a) doğrudan gözlem

b) taksona uygun bir bolluk endeksi

c) doluluk alanında, meydana gelme derecesi ve / veya yaşam alanı kalitesinde düşüş

d) fiili veya potansiyel sömürü seviyeleri

e) ilgili taksonda gözlenen hibridizasyonun, patojenlerin, kirleticilerin, rakiplerin veya parazitlerin etkileri.

2. A1 uyarınca (a) ila (e)'den herhangi birine dayanarak (ve belirtilerek) son 10 yıl veya üç kuşak boyunca popülasyon büyüklügünde $\geq 50 \%$ gözlenen, tahmin edilen, çıkarım veya şüpheli bir küçülme,

3. A1 altında b'den e'ye herhangi birine dayanarak (ve belirterek), önümüzdeki 10 yıl veya üç kuşak içinde öngörülen veya öngörüldüğünden şüphelenilen nüfusun $\geq \% 50$ 'lik bir popülasyon büyüklüğü azalması durumunda.

4. Gözlemlenen, tahmin edilen, çıkarılan, öngörülen veya kuşkulanılan popülasyonun, herhangi bir 10 yıl veya üç nesil boyunca \% 50'den fazla azalması, hangisi daha uzunsa (gelecekte maksimum 100 yil), burada sürenin her ikisini de içermesi gerekir. Geçmiş ve gelecek ve azaltma veya sebeplerinin sona ermeyeceği veya anlaşılamadığı durumlarda, A1 uyarınca (a) ila (e) 'den herhangi birine dayanarak (ve belirterek) geri dönüşümlü olmadığı durumlarda.

B. Coğrafik Dağılım Alanı B1 (oluşma derecesi) veya B2 (doluluk alanı) veyaher ikisi birlikte: tahminler:

$1.5000 \mathrm{~km}^{21}$ den az olduğu tahmin edilen dağılım alanı ve a bendinden c'ye en az ikisini gösteren

a) En fazla beş yerde var olduğu ve ciddi şekilde populasyonlarının parçalandığ bilinmektedir.

b) Aşağıdakilerin herhangi birinde gözlemlenen, çıkarılan veya öngörülen sürekli düşüş:

(i) meydana gelme derecesi

(ii) doluluk alanı

(iii) alan, kapsam ve / veya habitat kalitesi

(iv) yer veya alt popülasyon sayıs1

(v) yetişkin birey sayısı.

c) Aşağıdakilerden herhangi birinde aşırı dalgalanmalar:

(i) oluşma derecesi

(ii) doluluk alanı

(iii) yer sayıs1 veya alt nüfus

(iv) yetişkin birey sayısı. 
2. Dağılım alanının $500 \mathrm{~km}^{21} \mathrm{den}$ az olduğu tahmin edilmektedir ve a bendinden c'ye en az ikisini gösteren tahminler:

a) En fazla beş yerde var olduğu ve ciddi şekilde populasyonlarının parçalandığı bilinmektedir.

b) Aşağıdakilerin herhangi birinde gözlemlenen, çıkarılan veya öngörülen sürekli düşüş:

(i) meydana gelme derecesi

(ii) doluluk alanı

(iii) alan, kapsam ve / veya habitat kalitesi

(iv) yer veya alt popülasyon sayısı

(v) yetişkin birey sayısı.

c) Aşağıdakilerden herhangi birinde aşırı dalgalanmalar:

(i) oluşma derecesi

(ii) doluluk alanı

(iii) yer sayıs1 veya alt nüfus

(iv) yetişkin birey sayıs1. beraber;

C. Nüfus büyüklüğü olarak 2500 bireyden daha az yetişkin bireyin sayıldığı tahmin edilmekle

1. Beş y1l veya iki kuşak içinde, hangisi daha uzunsa (gelecekte maksimum 100 yıla kadar) en az\% 20'lik bir tahmini devam eden düşüş beklenmektedir.

2. Yetişkin bireylerin sayısında gözlenen, öngörülen veya çıkarılan ve devam eden bir düşüş ve aşağıdakilerden en az biri (a-b):

a) Aşağıdakilerden biri biçimindeki popülasyon yapısı: VEYA

(i) alt populasyonda 250 'den fazla yetişkin bireyin bulunmadığ 1 tahmin edilmektedir,

(ii) alt popülasyondaki bireylerin en az \% 95'i yetişkin bireylerden oluşmaktadır.

b) Yetişkin birey sayısında aşırı dalgalanmalar tespit edilmektedir.

D. Nüfus büyüklüğünün 250 yetişkin bireyden daha az olduğu tahmin edilmektedir.

E. Yabani tükenme olasılığını gösteren kantitatif analiz, 20 yıl veya beş kuşak içinde, hangisi daha uzunsa (en fazla 100 yıla kadar) en az \% 20 olarak tahmin edilmektedir.

\section{Sonuç ve Öneriler}

Bu çalışmada Türkiye ve İran' da yayılış gösteren bir İran-Turan endemiği ve elementi olan Tuzkırgını (Asparagus lycaonicus P.H. Davis) türünün koruma biyolojisi açısından güncel değerlendirmesinin yapılması hedeflenmiştir.

Tuzkırgını türünün her ne kadar İran populasyonu da tanımlanmış olsa da güncel durum itibariyle, İran'da tespit edildiği noktadan son 10 yıldır türe ilişkin güncel bir gözlem kaydı olmadığı da göz önünde tutulmalıdır. Bunun yanı sıra bu araştırma kapsamında gerçekleştirilen güncel arazi çalışmaları sonucunda da literatürden verilen yayılış lokalitesi bilgileri değişmemiş olup, dolayısıyla tür Türkiye'den halen daha tek bir lokaliteden (Konya İli Cihanbeyli İlçesi sınırlarında yer alan Bolluk Gölü'nün yoğun tuzlu ve sodalı kıyıları) bilinmektedir. Sonuç olarak tamamı ALKİM Alkali Kimya A.Ş.'ne ait fabrika yapılarının etrafında yaşayan yaklaşık 10 farklı populasyonun sayımı sonucunda 182'si meyve formunda olan 858 birey ile karşlaşılmıştır. Türün yaşadığ bilinen ve tarafimızca da güncel durumu teyit edilen tek lokalite olan Bolluk Gölü kıyısı boyunca gözlenen halofit (tuzcul ve sodalı) bozkırlar ve bölgede yaygın dağılış arz eden esas bozkır tipi ise İran-Anadolu Bozkırları'dır.

A. lycaonicus, Orta ve Kuzeydoğu İran'da birkaç yerden bilinen bir başka halofitik tür olan $A$. griffithii ile uzaktan ilişkili olan izole edilmiş bir tür gibi görünmektedir [8, 34]. Esasen Türkiye ve İran populasyonları arasındaki yaklaşık 1500 km'lik mesafe göz önüne alındığında; bu türün coğrafik ayrımı fitocoğrafik açıdan büyük ilgi çekmektedir. Buna duruma benzer örnekler sıklıkla farklı türler arasında da rapor edilmiştir [35]. Populasyonların bu denli uzak coğrafik ayrışmaları ve görece çok uzak dağılımlarını açıklayıcı çeşitli yorumlar bulunmakla beraber bu durumu en iyi açıklayacak olgu son buzul dönemlerinde yaşanan biyocoğrafik dönüşümler olarak göze çarpmaktadır. Öyle ki, baskın bitki örtüsünün Artemisia ve Chenopodiaceae türlerinden oluştuğu Pleistosen ve erken Holosen sirasındaki daha kuru iklim koşullarına dönme süreci bu ayrışmayı tetiklemiş olabilir [35]. 
Bununla birlikte türün İran populasyonunu uzun yıllardır araştıran Dr. Akhani, A. lycaonicus'un filogenetik ilişkisini ortaya çıkarmak ve Türk ve İran popülasyonlarını karşılaştırmak için Güneybatı Asya'daki Asparagus cinsi üzerine bizim de öngördüğümüz gibi moleküler çalışma yapılmasını önermektedir (Akhani; Kişisel yorum, 2019). Bu bilgiler doğrultusunda bölgedeki Asparagus cinsinin moleküler revizyonunun detaylı hesaplanacak uygun bir bütçe, uzman ekip ve yeterli zaman temin edilerek uluslararası bir proje ile yürütülebileceği anlaşılmaktadır. Bu çalışmalar tamamlandığı takdirde hem türün endemizm özellikleri hem de ulusal ve uluslararası koruma statüleri hakkında daha doğru tanımlamalar yapılabilecektir.

Türün İran'daki örneklerinin kendisi tarafindan yalnızca bir kez toplandığını ve populasyonun yaşadığı lokalitelerde son 10 yılda düzenli olarak yaptığı yeniden keşif çabalarının şu ana kadar başarısız olduğunu belirten Akhani, hidrolojik sebepler veya habitat değişimi nedeniyle bu küçük populasyonun neslinin tükenmiş olabileceğini ifade etmektedir. Bu verileri üst üste eklediğimizde her ne kadar tür mevcut durumu itibariyle şu an için yalnızca Orta Anadolu'daki populasyonlarından biliniyor olsa da halen daha İran'da türe ait populasyonların yaşama potansiyeli nazara dikkate alındığında türe yönelik endemizm tanımından kaçınmak gerektiğii bunun yerine İran-Turan Fitocoğrafik Bölgesi’ne özgü bir tür olarak tanımlamanın uygun olacağı tarafımızca önerilmektedir. Yapılacak olan daha ileri düzey botanik araştırmalar neticesinde, türün İran'daki populasyonlarının artık tamamen ortadan kalktığının anlaşılması durumunda Türkiye endemiği statüsünü alabileceği göz önünde tutulmalıdır.

Türe yönelik en kritik tehdidin türün habitatını doğrudan bozma ve yayılış alanını geri dönüşsüz biçimde yok etme, popülasyonun genişlemesini engelleme riskinden dolayı ALKIM Alkali Kimya A.Ş. (Cihanbeyli-Bolluk Tesisleri)'ne bağlı hafriyat, depolama, trafik ve diğer arazi kullanımları ile birlikte yaşam alanlarının yakın çevresinin tarım arazisine dönüştürülmesi olduğu anlaşılmıştır.

Mevcut literatür ve arazi çalışmalarına göre Tuzkırgını türünün biri ülkemizin Orta Anadolu Bölümü'nde yer alan Konya İli Cihanbeyli İlçesi sınırlarındaki Bolluk Gölü’nün yoğun tuzcul kıyı habitatlarından, bir diğeri de $1500 \mathrm{~km}$ uzaklıktaki İran'ın orta-kuzeybatı bölümünde yer alan Arak Bölgesi'nde bulunan Meighan-Arak Tuz Gölü'nün yoğun tuzcul kıyı habitatlarından olmak üzere 2 populasyona sahip olması dolayısıyla B1-a) kriterini, oldukça dar bir yayılış ve yaşam alanına sahip olması, yapılan güncel sayımlarda 2500'ün altında birey sayımı ve bunların 250'den daha azının olgun bireyler olmasından dolayı da C2-a(i) kriterini sağladığı anlaşılmaktadır. Öte yandan, araştırmanın yapıldığı Türkiye populasyonu özelinde; özel sektöre ait sodyum sülfat üretim faaliyetleri ve otlatma faaliyetleri nedeniyle yüksek tehdit altında bulunması da göz önüne alınarak bu türün IUCN tehlike kategorisinin EN B1-a, C2-a(i) statüsünde değerlendirilmesi önerilmektedir. Bununla beraber yapılan bu değerlendirme çerçevesinde yalnızca Türkiye populasyonunun dikkate alındığı, İran populasyonuna ait güncel verilerin de değerlendirmeye eklenmesine bağlı olarak ilgili kriterlerin ve statünün revize edilmesinin de yüksek olasılık dahilinde bulunduğu ifade edilmelidir. Sonuç olarak, esasen bu taksona ait ulusal koruma statüsü mevcut metotlar ışığında CR (Critically Endangered)/Kritik Düzeyde Tehlike Altında olması gerekirken, İran populasyonuna ait verilerden dolayı bir alt statü olan EN içerisinde tanımlanmış, ancak bu statü uluslararası ölçekte doğru iken, ulusal ölçekte CR statüsünde tanımlanması gerektiği önerilmektedir.

Türe yönelik farklı ölçeklerdeki tehditleri bertaraf edebilmek ve türün sürdürülebilir biçimde uzun vadede yaşamını sağlıklı populasyonlarla devam ettirebilmek amacıyla bilinen yaşam alanlarının mevcut haliyle korunmasını sağlayabilmek ve bu alanları belirli periyotlarda izleyebilmek, paydaşlar ve farklı yaş grupları arasıdna koruma motivasyonunu arttırabilmek amacıyla yerel ve ulusal düzeyde türün bilinirliğini arttırabilmek ve bilgi boşluklarını doldurabilmek temel koruma hedefleri olarak değerlendirilmelidir. Bu hedeflere ulaşabilmek içinse;

- Türün yayılım alanlarında izleme parselleri oluşturularak türü izlemek,

- Kolluk kuvvetlerini ve türün yayılış gösterdiği alanın kullanımından sorumlu ALKİM Alkali Kimya A.Ş. (Cihanbeyli-Bolluk Tesisleri) personelini tarafından arazi kullanımına yönelik düzenli denetimlere teşvik etmek ve bu gruba tür ve habitatı hakkında düzenli eğitimler vermek,

- Türün yayılış alanının iklim, hidroloji ve toprak özelliklerinin Tuzkırgını bitkisinin yayılışına olan etkilerini araştırmak,

- Türün yaşam alanlarının yakın çevresinin tarım arazisine dönüştürülmesinin önlenmesine yönelik önlemler almak, 
- Türün üreme başarısını ve diğer canlı türleri ile olan etkileşimini araştırmak,

- İran populasyonu ile karşılaştırmalı moleküler biyoloji çalışmalarını gerçekleştirmek,

- Tuzkırgını'nın doğal alanı dışında (ex-situ) korunması olanaklarını araştırmak gibi alt hedeflere yönelik kısa, orta ve uzun vadeli olarak belirlenen faaliyetler kapsamında bir eylem planı çerçevesinde uygulamaya geçirilmesi gerekmektedir.

\section{Teşekkür}

Bu araştırma, Doğa Koruma ve Milli Parklar Genel Müdürlüğü, VIII. Bölge Müdürlüğü, Konya İl Şube Müdürlüğü uhdesinde, 2019 yılı içerisinde "NARTUS Enerji ve Çevre Yat. Müş. Mad. San. ve Dış Tic. Ltd. Şti." tarafindan yürütülen 'TUZKIRGINI (Asparagus lycaonicus P.H. Davis) TÜR KORUMA EYLEM PLANI' işi kapsamında tamamlanmıştır. Araştırmanın arazi çalışmaları sırasındaki desteklerinden ve haritalama çalışmalarındaki katkılarından dolayı "NARTUS Enerji ve Çevre Yat. Müş. Mad. San. ve Dış Tic. Ltd. Şti." çalışanlarına, araştırmanın her aşamasındaki gerekli izinlerin ve bilgilerin sağlanması, lojistik desteklerin sunulması ve diğer katkılarından dolayı Doğa Koruma ve Milli Parklar Genel Müdürlügü özelinde tüm T.C. Tarım ve Orman Bakanlığı, VIII. Bölge Müdürlügü, Konya İl Şube Müdürlügü yetkililerine ve çalışmaya gösterdikleri özel ilgi ve desteklerinden dolayı Cihanbeyli Kaymakamı Sn. Mustafa KUTLU’ya teşekkürlerimizi sunarız.

\section{Yazarların Katkısı}

Çalışmaya yazarlar eşit oranda katkı sunmuşlardır.

\section{Çıkar Çatışması Beyanı}

Yazarlar arasında herhangi bir çıkar çatışması bulunmamaktadır.

\section{Araştırma ve Yayın Etiği Beyanı}

Yapılan çalışmada, araştırma ve yayın etiğine uyulmuştur. Araştırma etik kurul izni gerektirmemektedir.

\section{Kaynaklar}

[1] Demirayak F. 2002. Biyolojik Çeşitlilik-Doğa Koruma Ve Sürdürülebilir Kalkınma. TÜBITAK VIZYON 2023 Projesi Çevre ve Sürdürülebilir Kalkınma Paneli.

[2] Özhatay N., Byfield A., Atay S., 2005. Türkiye'nin 122 Önemli Bitki Alanı. Doğal Hayatı Koruma Vakfı (WWF Türkiye) yayını, İstanbul.

[3] Eken G., Bozdoğan M., İsfendiyaroğlu S., Kılıç D.T., Lise Y. (eds.). 2006. Türkiye'nin Önemli Doğa Alanları. 2 Cilt. Doğa Derneği, Ankara.

[4] Doğa Araştırmaları Derneği, 2014. Tür Eylem Planı Hazırlama Rehberi. 31 Syf., Ankara. http://www.turkiyeninturnalari.org/tr/wp-content/uploads/2016/05/eylem_plani_rehber.pdf (Erişim tarihi: 20.04.2020).

[5] Davis P.H. 1983. Notes R.B.G. Edinb. University Press, Edinburgh, 41: 48.

[6] Davis P.H., 1984. Asparagus L. In: Davis P.H. (ed.), Flora of Turkey and the East Aegean Islands, Vol. 8, University Press, Edinburgh, pp. 75-81.

[7] Akhani H. 2002. Notes On The Flora Of Iran: 1. Asparagus (Asparagaceae) and Nitraria (Zygophyllaceae). Edinburgh Journal Of Botany, 59 (2): 295-302.

[8] Browicz K. 1990. Asparagus. In: Rechinger K.H. (ed.) Flora Iranica. Graz, Akademische Drucku.-Verlagsanstalt, 165:167-176.

[9] Ekim T., Koyuncu M., Vural M., Duman H., Aytaç Z., Adıgüzel N. 2000. Türkiye Bitkileri Kırmızı Listesi, (Red Data Book of Turkish Plants (Pteridophyta and Angiospermae)). Türkiye Tabiatını Koruma Derneği ve Van 100. Y1l Üniversitesi Yayını, Ankara, 1-246.

[10] Güner A., Aslan S., Ekim T., Vural M., Babaç M.T. 2012. Türkiye Bitkileri Listesi (Damarlı Bitkiler). Nezahat Gökyiğit Botanik Bahçesi ve Flora Araştırmaları Derneği Yayını, İstanbul, 11290. 
[11] Güvenç A. 1996. Türkiye'de yetişen Asparagus (Kuşkonmaz) türleri üzerinde farmasötik botanik yönünden araştırmalar. Doktora Tezi, Ankara Üniversitesi, Sağlik Bilimleri Enstitüsü, Ankara.

[12] Özler H. 2001. Asparagus L., Allium L., Muscari Miller ve Fritillaria L. (Liliaceae) cinslerine ait bazı türlerin polenlerinin morfolojik yapılarının incelenmesi. Doktora Tezi, Gazi Üniversitesi, Fen Bilimleri Enstitüsü, Ankara.

[13] Plant Dergisi, 2017. NGBB'de Kurak ve Çorak Bahçe. https://www.plantdergisi.com/ngbb-dekurak-ve-corak-bahce.html (Erişim tarihi: 15.04.2020).

[14] Atlas Dergisi, 2010. Yok Olmadan Önce Görülmesi Gereken - Son Cennetler Atlası. Atlas Özel Koleksiyon, İstanbul, 96.

[15] Angiosperm Phylogeny Group, 2016. An update of the Angiosperm Phylogeny Group classification for the orders and families of flowering plants: APG IV. Botanical Journal of the Linnean Society, 181 (1): 1-20.

[16] Dahlgren R.M.T., Clifford H.T., Yeo P.F. 1985. The families of monocotyledons: structure, evolution, and taxonomy. Springer, Berlin.

[17] Clifford H.T., Conran J.G. 1987. Asparagaceae. In: George AS (ed) Flora of Australia. Australian Government Publishing Service, Canberra, 159-164.

[18] Güvenç A. 1997. Asparagus Türlerinin taşıdığı etken bileşikler ve kullanılışları. A.Ü. Ecz. Fak. Der., 26 (1): 52-75.

[19] Bailey L.H. 1950. The Standart Cyclopedia of Horticulture. In Three Vol, 1A-E, The Mcmillan Company, 406-411.

[20] Tutin T.G., Heywood V.H., Burges N.A., Moore D.M., Valentine D.H., Walters S.M., Webb D.A. 1980. Flora Europaea. Vol.5, Cambridge Univercity Press, Cambridge, 71-73.

[21] Güvenç A. 1998. Türkiye'de yetişen Asparagus türlerinin gövde anatomisi. Ankara Ecz. Fak. Derg., 27 (1): 73-91.

[22] Güvenç A., Koyuncu M. 1999. Türkiye'de Yetişen Asparagus L. (Kuşkonmaz) Türlerinin Kök Anatomisi. Ankara Ecz. Fak. Derg., 28 (1):15-36.

[23] Braun-Blanquet J. 1932. Plant Sociology: the Study of Plant Communities. English translation of Pflanzensoziologie (Translated by Fuller, G.D. and H.S. Conard), McGraw-Hill. New York.

[24] Canfield R.H. 1941. Application of the Line Interception Method in Sampling Range Vegetation. Journal of Forestry, 39: 388-394.

[25] Thanos C.A., Marcou S. 1991. Post-fire regeneration in Pinus brutia ecosystems of Samos Island (Greece): 6 years after. Acta Oecologica, 12 (5): 633-642.

[26] Diersing V.E., Shaw R.B., Tazik D.J. 1992. US Army Land Condition-Trend Analysis (LCTA) Programme. Enviromental Management, 16: 405-414.

[27] Tazik D.J., Warren S.D., Diersing V.E., Shaw R.B., Brozka R.J., Bagley C.F., Whitworth W.R. 1992. U.S. Army Land Condition-Trend Analysis (LCTA) Plot Inventory Field Methods. USACERL Technical Report N-92/03. Champaign, IL.

[28] Carrington M.E., Keeley J.E. 1999. Comparision of post-fire seedling establishment between scrub communities in Mediterranean and non-Mediterranean climate ecosystems. Journal of Ecology, 87: 1025-1036. [29]

[29] Stylinski C.D., Allen E.B. 1999. Lack of native species recovery following severe exotic distuurbance in southern Californian shrublands. Journals of Applied Ecology, 36: 544-554.

[30] Bonham C.D. 1989. Measurements for terrestrial vegetation. Wiley Intersciences Series, N.Y., 1346.

[31] Avrupa Çevre Ajans1, 2020. Bern Sözleşmesi Ekleri. https://www.coe.int/en/web/bernconvention/appendices (Erişim tarihi: 07.07.2020).

[32] CITES, 1983. Nesli Tehlike Altında Olan Yabani Hayvan ve Bitki Türlerinin Uluslararas1 Ticaretine İliş̧kin Sözleşme Sözleşmesi (CITES SÖZLEŞMESİ), Ek Liste-II.

[33] International Union for Conservation of Nature-IUCN, 2020. Red List Categories and Criterias, Gland-Switzerland. www.iucnredlist.org,IUCN Red List 2020.1, Gland-Switzerland (Erişim tarihi: 10.04.2020).

[34] Akhani H. 1998. Plant biodiversity of Golestan National Park, Iran. Stapfia, 53: 1-411.

[35] Hedge I.C. 1997. Microcnemum Ungern-Sternb. (Chenopodiaceae). In: Rechinger, K. H. (ed.) Flora Iranica, Graz: Akademische Druck-u.-Verlagsanstalt, 172: 132-133. 